\title{
Health risk assessments of arsenic and toxic heavy metal exposure in drinking water in northeast Iran
}

Hosein Alidadi ${ }^{1,4+}$, Seyedeh Belin Tavakoly Sany ${ }^{2,4+}$ BD , Batoul Zarif Garaati Oftadeh ${ }^{3,47^{*}}$, Tafaghodi Mohamad ${ }^{5,7}$, Hosein Shamszade ${ }^{6}$ and Maryam Fakhari ${ }^{7}$

\begin{abstract}
Background: Arsenic and heavy metals are the main cause of water pollution and impact human health worldwide. Therefore, this study aims to assess the probable health risk (non-carcinogenic and carcinogenic risk) for adults and children that are exposed to arsenic and toxic heavy metals ( $\mathrm{Pb}, \mathrm{Ni}, \mathrm{Cr}$, and $\mathrm{Hg}$ ) through ingestion and dermal contact with drinking water.

Method: In this study, chemical analysis and testing were conducted on 140 water samples taken from treated drinking water in Mashhad, Iran. The health risk assessments were evaluated using hazard quotient (HQ), hazard index (HI), and lifetime cancer risk (CR).

Results: The results of the HQ values of arsenic and heavy metals for combined pathways were below the safety level $(\mathrm{HQ}<1)$ for adults, while the $\mathrm{HI}$ for children were higher than the safety limit in some stations. Likewise, $\mathrm{Cr}$ showed the highest average contribution of $\mathrm{HI}_{\text {total elements }}$ (55 to 71.2\%) for adult and children population. The average values of total carcinogenic risk (TCR) through exposure to drinking water for children and adults were $1.33 \times 10^{-4}$ and $7.38 \times 10^{-5}$, respectively.

Conclusion: Overall, the $C R_{\text {total }}$ through exposure to drinking water for children and adults was borderline or higher than the safety level of US EPA risk, suggesting the probability of carcinogenic risk for the children and adults to the carcinogenic elements via ingestion and dermal routes. Therefore, appropriate purification improvement programs and control measures should be implemented to protect the health of the residents in this metropolitan city.
\end{abstract}

Keywords: Human health risk assessment, Heavy metal pollution, Arsenic, Carcinogenic and non-carcinogenic effects

\section{Introduction}

Heavy metals and arsenic contamination in drinking water poses a serious threat to human life because of their toxicity, bio-accumulative nature, and persistence in the environment [1-3]. The heavy metals contaminate the groundwater and surface water through a natural

\footnotetext{
*Correspondence: zarifbety@gmail.com

${ }^{\dagger}$ Hosein Alidadi and Seyedeh Belin Tavakoly Sany contributed equally as first authors to this work

${ }^{3}$ Students Research Committee, Mashhad University of Medical Sciences, Mashhad, Iran

${ }^{4}$ Social Determinants of Health Research Center, Mashhad University of Medical Sciences, Mashhad, Iran

Full list of author information is available at the end of the article
}

process and anthropogenic activities (e.g., industrial, agricultural, mining, and traffic activities) $[4,5]$. According to the World Health Organization (WHO) report 2015, $71 \%$ of the global population uses safely managed drinking water sources [6]. This includes piped treated water that is located on premises and protected dug wells $[7,8]$. However, safely managed water sources can still be polluted by toxic elements due to the poor domestic treatment system, use of chemical materials in the water treatment system, pipeline corrosion, leaching of elements from pipes of water distribution, and use of improper storage containers and poorly maintained filtration for drinking water at home $[9,10]$. To date, most of the

(c) The Author(s). 2019 Open Access This article is distributed under the terms of the Creative Commons Attribution 4.0 International License (http://creativecommons.org/licenses/by/4.0/), which permits unrestricted use, distribution, and reproduction in any medium, provided you give appropriate credit to the original author(s) and the source, provide a link to the Creative Commons license, and indicate if changes were made. The Creative Commons Public Domain Dedication waiver (http://creativecommons.org/publicdomain/zero/1.0/) applies to the data made available in this article, unless otherwise stated. 
developing countries are faced with this challenge, usually due to their limited economic capacities to use advanced technologies for heavy metal removal [6].

The greatest threat of toxic heavy metals and arsenic is reported in the drinking water and groundwater of several countries, including Mexico, Saudi Arabia, India, Bangladesh, China, Chile, Thailand, and Iran [1, 7]. In Sonora, Mexico, approximately $43 \%$ of a drinking water sample from storage tanks and wells were observed to have elevated levels of $\mathrm{Cd}$, $\mathrm{As}, \mathrm{Hg}, \mathrm{Cu}$, and $\mathrm{Pb}$ [7]. The concentrations of $\mathrm{Cd}, \mathrm{Pb}$, and $\mathrm{Cu}$ in drinking water in ten cities of Saudi Arabia exceeded the guideline value, which was attributed to the Kuwaiti and the Gulf War oil fires [11]. The concentrations of $\mathrm{Mn}, \mathrm{Cd}$, and $\mathrm{Pb}$ in drinking water in India exceeded the guideline value, which was attributed to the geo-genic contamination [12]. In the last 10 years, data on heavy metal contamination of groundwater in most rural areas of India showed that the average concentrations of As, Mn, Cr, $\mathrm{Pb}, \mathrm{Ni}$, and $\mathrm{Zn}$ in drinking water exceeded the WHO guidelines, which was linked to the pharmaceutical, paint, pesticide and fertilizer industries [11, 12]. In the last 14 years, data on As contamination in Bangladesh showed that $42.1 \%$ of the drinking samples had As above $50 \mu \mathrm{g} / \mathrm{L}[9,13]$. The average concentrations of $\mathrm{Pb}, \mathrm{Cr}$, $\mathrm{Ni}$, and $\mathrm{Zn}$ in drinking water in some metropolitan cities of Iran [14-16] and Thailand $[4,17]$ exceeded the guidelines value, which was linked to the pipeline corrosion and poor domestic treatment.

Several studies have evaluated the level of toxic metals in drinking water and reported that the concentrations of these metals from Germany, USA, Jordan, Malaysia, and Turkey are below permissible limits [7, 9, 18]. However, comparisons with standards alone are not enough to quantitatively assess the health risk of toxic element exposure via consumption of drinking water. Human health risk assessments models are recently implemented to examine whether exposure to toxic elements could increase the incidence of adverse effect on human health [19-22].

Studies showed that population growth, increasing water scarcity, urbanization, and climate change are great challenges for drinking water supply systems. By 2025 , more than $50 \%$ of the global population will be living in water-stressed regions, particularly low- and middle-income countries [7]. Therefore, a determination of the level of heavy metals in different water sources is important for proper human health risk assessment [7, 9]. According to the Environmental Protection Agency (EPA) and Agency for Research on Cancer (IARC), exposure to inorganic arsenic and toxic heavy metals are of major concern in drinking water, mainly due to their carcinogenic and non-carcinogenic effects on human health. Arsenic, $\mathrm{Cd}$, and $\mathrm{Cr}$ in drinking water have been pointed as a public health concern in $>30$ countries. It was evidenced that drinking $1 \mathrm{~L} /$ day drinking water with As dose of $50 \mu \mathrm{g} \mathrm{L}{ }^{-1}$ and $\mathrm{Cr}$ dose of 8.3-51 over one's lifetime may cause of the cancer of the lung, liver, bladder, and kidney [11,23]. It was also found that skin damages and respiratory disorders were increased from an As dose of $0.0012 \mathrm{mg} / \mathrm{kg} /$ day through drinking water. Long-term exposure to $\mathrm{Cd}$ leads to chronic renal failure, anosmia, anemia, cardiovascular diseases, hypertension, and osteoporosis [11]. Other effects such as anemia from $\mathrm{Pb}$ [9], gastrointestinal disorder from $\mathrm{Cu}[9,10]$, kidney and liver damage from $\mathrm{Hg}$, and blood cholesterol $[10,24]$ and heart diseases from $\mathrm{Sb}$ were also reported $[9,10,24]$.

In Iran, although, $96 \%$ of the cities have access to safe water supply systems, drinking water supply can still be contaminated by arsenic and heavy metals [15]. They demonstrated that due to the improper waste disposal and pipeline corrosion, there is an increase in the pollution level of water supply, which in turn has led to increasing skin lesion and incidence of cancer in Iran $[14,15]$. This work is the first study of arsenic and heavy metal exposure, in which we provide more knowledge about their dispersion pattern and non-carcinogenic and carcinogenic health risk in Mashhad, Iran.

Several studies have been conducted on evaluating the heavy metal contamination in different environmental matrices (e.g., sediment, soil, and foodstuff) [5, 25]; however, no background and updated databases are available on health risk of toxic heavy metals through drinking water consumption in this region.

Available monitoring data on heavy metals from the village areas of Mashhad have shown symptoms of As and toxic heavy metal contamination [14, 15, 26]. With regard to the importance of Mashhad as the second metropolitan city in Iran (religious capital of Iran) and great industrial and tourism center (25 million per years) [27], greater attention needs to be provided regarding reliable heavy metal information in municipal water distribution system. The aims of this study were to (1) examine the concentrations of arsenic and toxic heavy metals $(\mathrm{Cr}, \mathrm{Hg}, \mathrm{Pb}$, and $\mathrm{Ni})$ in piped treated water to characterize drinking water quality and (2) to estimate the health risks (non-carcinogenic and carcinogenic) for the residents exposed to arsenic and toxic elements through ingestion and dermal contact with piped treated water.

\section{Materials and methods}

\section{Study area description}

Mashhad is the second largest metropolitan city in Iran, which is located in the northeast of Iran, bordering Turkmenistan and Afghanistan between the longitudes of $58^{\circ} 20^{\prime}$ to $60^{\circ} 8^{\prime}$ and latitudes $35^{\circ} 40^{\prime}$ to $36^{\circ} 3^{\prime}$ of Iran 
(Fig. 1, Table 1) [27]. This city covers a total area of 16, $500 \mathrm{~km} 2$, which is limited to the south by Binaloud Mountain, to the north by Hezar Masjid heights, to the southeast by Jamroud river basin, and northwest by Atrak river basin $[28,29]$. Mashhad has a population of 3.004 million, of which $97.5 \%$ are Persians and $2 \%(0.054$ million) are Pakistani, Afghani, Turkish, and Arab. The region climate is cold and dry [29]. In this city, the supply of drinking water originates from rivers, wells, and groundwater. The conventional water treatment system was used to treat drinking water in Mashhad, and it is distributed through a pipeline system consisting of high-density polyethylene (HDPE) pipes and mild steel $[28,29]$. The present study area has suffered several environmental pollutants due to the fastest-growing industrial zones (leather goods, metal products, dyeing, fertilizers, textile, chemical, and so on) and economic development coupled with agricultural activities [5, 29]. The wastewater from agricultural and industrial zones is discharged into the natural rivers and dam and eventually permeates through the groundwater that is used for drinking purpose. This results in a rapid release of heavy metals and other chemical toxins into water sources and subsequently to the human body via the food chain [27, 29]. Furthermore, a large part of the pipeline construction in the present study area is old [29]. Therefore, pipeline corrosion may affect the concentration of heavy metals in the municipal water distribution system.

\section{Sampling, preservation, and transportation}

On the basis of location and land uses, five sites (north, south, east, west, and center) having 35 stations were selected for drinking water sampling. All stations were sampled over four times, twice each in the dry (August

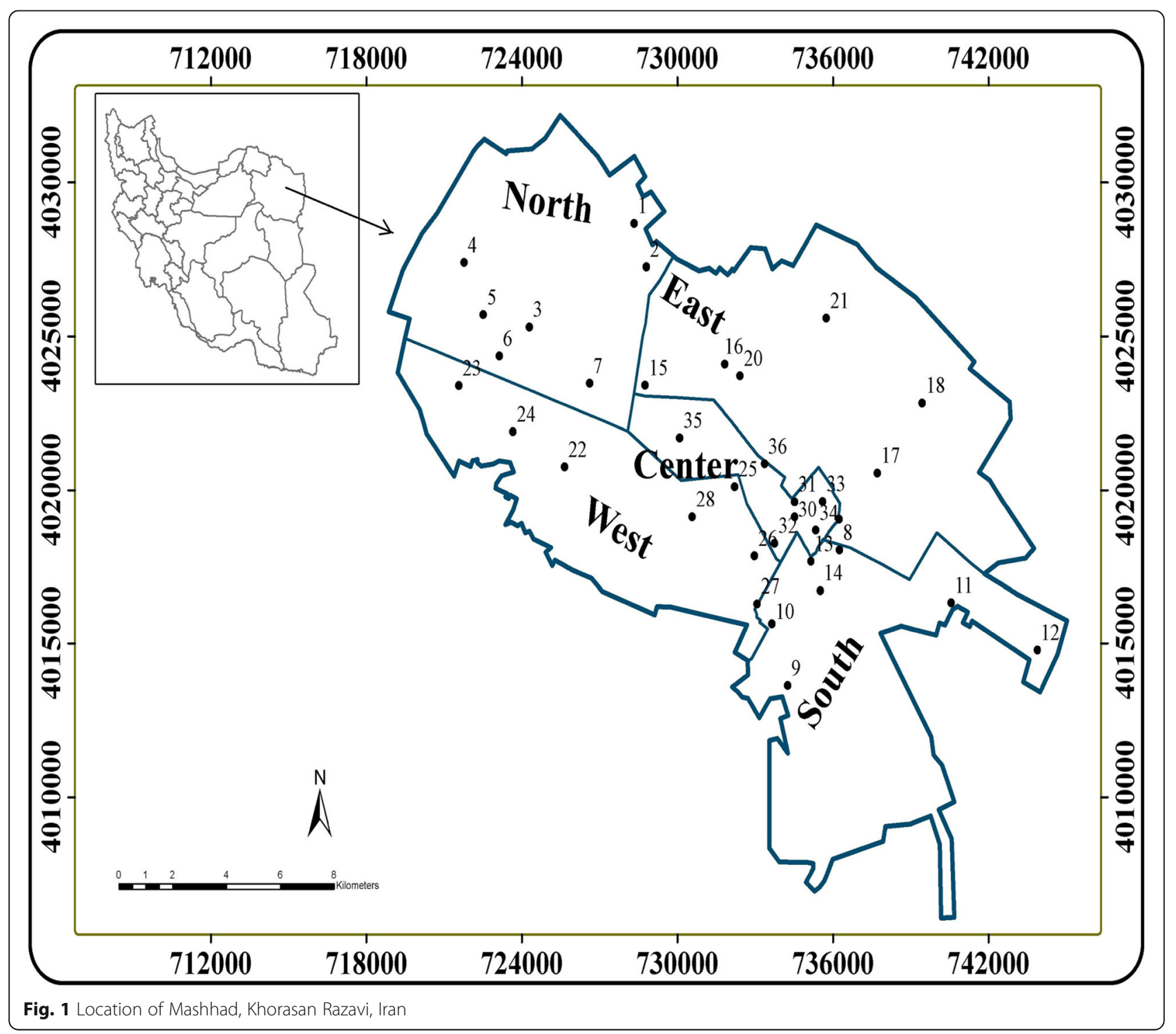


Table 1 Characteristics of sampling stations and statistics of heavy metal concentrations $\left(\mu \mathrm{L}^{-1}\right)$

\begin{tabular}{|c|c|c|c|c|c|c|c|c|}
\hline Sites & Stations & Latitude & Longitude & As & $\mathrm{Hg}$ & $\mathrm{Pb}$ & $\mathrm{Cr}$ & $\mathrm{Ni}$ \\
\hline \multirow[t]{7}{*}{ North } & 1 & 4029710 & 727406 & 0.15 & $N D$ & 0.83 & 0.415 & 1.22 \\
\hline & 2 & 4027701 & 728482 & 0.14 & ND & 0.415 & 0.565 & 0.9 \\
\hline & 3 & 4025335 & 724454 & 0.12 & ND & 0.705 & 0.97 & 3.2 \\
\hline & 4 & 4027198 & 721742 & 0.27 & ND & 1.065 & 6.03 & 1.225 \\
\hline & 5 & 4025914 & 725243 & 0.15 & ND & 0.485 & 2.725 & 1.555 \\
\hline & 6 & 4018132 & 735467 & 0.25 & ND & 0.705 & 3.65 & 1.885 \\
\hline & 7 & 4018221 & 735984 & 0.20 & ND & 0.365 & 17.67 & 0.45 \\
\hline \multirow[t]{7}{*}{ South } & 8 & 4017602 & 736047 & 0.17 & ND & 0.36 & 0.36 & 0.795 \\
\hline & 9 & 4014001 & 733598 & 0.09 & ND & 0.525 & 0.535 & 0.395 \\
\hline & 10 & 4014963 & 733130 & 0.20 & ND & 0.485 & 3.825 & 1.09 \\
\hline & 11 & 4016330 & 740638 & 0.21 & ND & 0.385 & 8.245 & 0.185 \\
\hline & 12 & 4014951 & 743628 & 0.18 & ND & 0.31 & 8.265 & 1.27 \\
\hline & 13 & 4023448 & 728776 & 0.14 & ND & 0.59 & 6.41 & 1.31 \\
\hline & 14 & 4024096 & 731871 & 0.18 & ND & 0.395 & 10.21 & 0.36 \\
\hline \multirow[t]{7}{*}{ East } & 15 & 4020529 & 737745 & 0.10 & ND & 0.33 & 0.68 & 0.28 \\
\hline & 16 & 4022731 & 739408 & 0.19 & ND & 0.515 & 11.17 & 0.23 \\
\hline & 17 & 4023714 & 732412 & 0.12 & ND & 0.375 & 23.25 & 1.715 \\
\hline & 18 & 4025587 & 735752 & 0.28 & ND & 0.625 & 0.47 & 1.815 \\
\hline & 19 & 4025452 & 734910 & 0.21 & ND & 0.495 & 0.565 & 0.35 \\
\hline & 20 & 402041 & 728081 & 0.15 & ND & 0.56 & 0.59 & 0.58 \\
\hline & 21 & 4023401 & 721575 & 0.16 & ND & 0.75 & 4.16 & 0.86 \\
\hline \multirow[t]{7}{*}{ West } & 22 & 4024240 & 723377 & 0.16 & 0.2 & 0.54 & 2.415 & 1.715 \\
\hline & 23 & 4021934 & 723688 & 0.39 & ND & 1.33 & 6.34 & 13.145 \\
\hline & 24 & 4023475 & 726604 & 0.18 & ND & 0.31 & 7.51 & 0.4 \\
\hline & 25 & 4021665 & 730176 & 0.18 & ND & 0.625 & 0.315 & 3.05 \\
\hline & 26 & 4020791 & 733368 & 0.23 & ND & 0.53 & 1.185 & 2.96 \\
\hline & 27 & 4019883 & 732363 & 0.24 & ND & 0.64 & 4.455 & 1.405 \\
\hline & 28 & 4017836 & 732942 & 0.20 & ND & 0.745 & 5.56 & 2.47 \\
\hline \multirow[t]{7}{*}{ Center } & 29 & 4016239 & 733048 & 0.23 & ND & 0.505 & 4.08 & 1.49 \\
\hline & 30 & 4019093 & 730563 & 0.20 & ND & 0.54 & 2.525 & 1.145 \\
\hline & 31 & 4019123 & 734946 & 0.14 & ND & 0.56 & 1.59 & 1.515 \\
\hline & 32 & 4017372 & 734784 & 0.16 & 0.2 & 0.575 & 7.875 & 0.95 \\
\hline & 33 & 4019664 & 734467 & 0.13 & ND & 0.45 & 1.435 & 1.59 \\
\hline & 34 & 4018134 & 734290 & 0.20 & 0.1 & 0.81 & 19.5 & 3.63 \\
\hline & 35 & 4019632 & 735625 & 0.14 & ND & 0.635 & 0.4 & 1.19 \\
\hline \multicolumn{4}{|l|}{ Mean } & 0.18 & 0.01 & 0.58 & 4.94 & 1.69 \\
\hline \multicolumn{4}{|c|}{ Standard deviation } & 0.05 & 0.048 & 0.206 & 5.53 & 2.15 \\
\hline \multicolumn{4}{|c|}{ *Asymp sig } & 0.01 & $<0.001$ & 0.02 & $<0.001$ & 0.03 \\
\hline \multicolumn{4}{|c|}{ RfD via ingestion pathway (mg/kg/day) } & 0.0003 & 0.0003 & 0.0035 & 0.003 & 0.02 \\
\hline \multicolumn{4}{|c|}{ RfD via dermal pathway (mg/kg/day) } & 0.000285 & 0.0003 & 0.000525 & 0.000075 & 0.0003 \\
\hline
\end{tabular}

*Asymptotic significant at $p<0.05$ based on Kruskal-Wallis test and testing significant change on the spatial variation of arsenic and toxic elements in drinking water from 35 stations 
and September 2017) and rainy (March and April 2017) seasons. We used cleaned plastic bottles pre-washed with double distilled water and $20 \% \mathrm{HNO}^{3}$ to collect water samples [30]. The samples were filtered using a $0.45-\mathrm{mm}$ Whatman pore membrane and acidified with $3 \mathrm{ml}$ nitric acid $\left(\mathrm{HNO}^{3}, 69 \%\right)$ to prevent adsorption and crystallization of trace element prior to further analysis. Then, water samples were transported in cool and dark containers and stored in a refrigerator at $4{ }^{\circ} \mathrm{C}$ until laboratory analysis [30].

\section{Chemical analysis}

All the acids, reagents, and standard solution (standard stock solutions, internal standard solutions, and a multi-element solution) were purchased from Merck (Darmstadt, Germany). All filtered and acidified drinking water samples were analyzed for As and toxic heavy metals $(\mathrm{Hg}, \mathrm{Ni}, \mathrm{Cr}$, and $\mathrm{Pb})$ by using inductively coupled plasma mass spectrometry (ICP-MS, 7700 series) under EPA method 6020 [9] (Additional file 1: Table S1). We used the blank and standards solutions of metal ions to obtain the calibration graph. The calibration blank (analytic-free media) was used with prepared standards to calibrate the ICP-MS (establishing a "zero" setting) and to confirm the absence of interferences in the analytical signal. The standard solution was made using different concentrations of elements following a range of metal ions based on previous studies and the limit of detection (LOD). The correlation coefficients of calibration lines for each metal were found to be greater than 0.99 .

\section{Quality control and assurance}

Glass containers and plastic bottles used during the analysis procedures were acid washed in diluted nitric acid solution (HNO3) for $24 \mathrm{~h}$ and rinsed using deionized water. Then, bottles were dried at room temperature and kept sealed. The instrumental LOD for water samples was estimated by a standard procedure. The LOD for each heavy metal ion was As $(0.11 \mu \mathrm{g} / \mathrm{L}), \mathrm{Cr}(0.06)$, $\mathrm{Hg}$ (0.01), $\mathrm{Pb}(0.15)$, and $\mathrm{Ni}(0.22)$, respectively. In order to check the reproducibility of the analysis, each sample was measured in triplicate. In this study, standard reference solutions with known concentration of the heavy metals (spiked solation) were used as control samples to check the measurement precision. Certified reference materials (CRMs) and standard reference solutions with known concentration of elements are recognized to be an essential tool for assuring the quality and establishing the accuracy of the results for the measurements of heavy metals by ICP-MS [9]. After each batch of ten samples, the control sample was analyzed to check the accuracy of the analysis. Recovery rates for each element were in acceptable ranges (85.7-115\%). Accepted recovery ranged from 80 to $120 \%$. All concentrations of As and elements were reported in $\mu \mathrm{g} \mathrm{L}^{-1}$ on a fresh weight basis. We used the average concentration of each element for further interpretation because the reproducibility was at 95\% confidence level. All these analyses were conducted in the water quality laboratory of Water Authority of Khorasan Razavi Province, Iran.

\section{Health risk assessment \\ Problem formulation}

According to the United States Environment Protection Agency (US EPA), the further intake of As and heavy metals such as $\mathrm{Ni}, \mathrm{Cr}, \mathrm{Pb}$, and $\mathrm{Hg}$ through drinking water may increase the non-carcinogenic and carcinogenic risk on human health [22]. Therefore, in the present study, the first assumption about health risk was that there is a serious carcinogenic or non-carcinogenic risk posed by As and toxic elements via the consumption of drinking water in Mashhad, Iran. Another assumption was that the dermal exposure of As and toxic elements from drinking water contributes to increasing the health risk in the study area. In the recent decade, the US EPA suggests that the human health risk assessment (HHRA) model measures the potential health risk of investigated contaminants using exposure and toxicity determination $[19,22]$.

\section{Exposure assessment}

Average daily dose (ADD) was implemented to estimate human exposure dose to arsenic and toxic metals through direct ingestion and dermal absorption pathways using Eqs. (1) and (2), which were adapted from the US EPA 2004 and 2005 [19, 22]. Estimations were conducted for two groups; children (as a sensitive group) and adults (as the general population), separately.

$$
\begin{aligned}
& \mathrm{ADD}_{\text {ing }}=\left(\mathrm{C} \times \mathrm{IR}_{\mathrm{d}} \times \mathrm{EF} \times \mathrm{ED}\right) / \mathrm{BW} \times \mathrm{AT} \\
& \mathrm{ADD}_{\text {derm }}=(\mathrm{C} \times \mathrm{SA} \times \mathrm{SL} \times \mathrm{ABS} \times \mathrm{EF} \times \mathrm{ED}) / \mathrm{BW} \times \mathrm{AT}
\end{aligned}
$$

where ADD is expressed as average daily dose of elements through ingestion pathways $\left(\mathrm{ADD}_{\mathrm{ing}}\right)$ and dermal absorption $\left(\mathrm{ADD}_{\mathrm{derm}}\right)\left(\mu \mathrm{g} \mathrm{kg}^{-1} \mathrm{day}^{-1}\right), \mathrm{C}$ is the concentration of the heavy metals $\left(\mu \mathrm{g} \mathrm{L}^{-1}\right), \mathrm{IR}_{\mathrm{d}}$ is the daily ingestion rate $\left(\mathrm{L} \mathrm{day}^{-1}\right)$, and its average consumption rates for Iranian children and adults is 1.8 and 21 per day [31], respectively. The body weight (BW) of child and adult groups is 16 and $70 \mathrm{~kg}$, respectively. ED expressed as the duration of human exposure for children and adults is 6 and 30 years [31], EF is exposure frequency (365 days year ${ }^{-1}$ ), and AT is averaging time of human exposure, At $=70 \times 365$ for carcinogenic and AT $=\mathrm{ED} \times$ 365 days for non-carcinogenic. SL, the skin adherence factor, for children and adults was 200 and $70\left(\mu \mathrm{g} \mathrm{cm}^{2} \mathrm{~h}^{-1}\right)$, 
respectively. SA is skin surface area for contact with water for children $\left(2800 \mathrm{~cm}^{2}\right)$ and adults $\left(5700 \mathrm{~cm}^{2}\right)$, and ABS is the dermal absorption factor, $\mathrm{ABS}=0.01$ for carcinogenic, and $\mathrm{ABS}=0.001$ for non-carcinogenic.

\section{Non-carcinogenic risks}

We used Eqs. (3) and (4) to estimate the noncarcinogenic risks using the target hazard quotient (THQ) and hazard index (HI) [22]. THQ is the ratio between the reference dose (RfD) and ADD of each element. In this study, the RfD of each element was adopted from US EPA screening levels [32]. The exposed population is assumed to be safe when HQ lower than $1[19,22]$.

$$
\begin{aligned}
& \text { THQ }=\text { CDI } / \text { RfD } \\
& \text { Total THQ }(H I)=\sum \text { THQ }
\end{aligned}
$$

where $\operatorname{RfD}$ is the oral reference dose $\left(\mu \mathrm{gg}^{-1}\right.$ day $\left.^{-1}\right)$ that indicate "the daily exposure to which the human population could be continually exposed over a lifetime without an appreciable risk of deleterious effects." We also estimated $\mathrm{HI}$ to measure the total non-carcinogenic risks from different exposure pathways [22].

\section{Carcinogenic risks}

EPA defined carcinogenic or cancer risks (CR) as "the incremental probability of an individual to develop cancer, over a lifetime, as a result of exposure to a potential carcinogen" [33]. We used Eq. (5) to estimate the carcinogenic risks. The cancer slope factor (CSF) value $\left(\mu \mathrm{g} \mathrm{kg}^{-1} \mathrm{day}^{-1}\right)$ is only available for $\mathrm{As}, \mathrm{Pb}$, and $\mathrm{Cr}$ $[10,32]$, which were adopted from US EPA screening levels [32]. A risk level of $1 \times 10^{-6}$ has been considered as the point of excess cancer risk, indicating 1 per 1,000,000 chance of getting cancer via consumption of drinking water containing arsenic and toxic metals, estimated in $\mu \mathrm{g} \mathrm{L}^{-1}$ for 70 years. The safe point for carcinogenic risks must be lower than this level [10]. The range of risks borderline by the EPA is $1 \times 10^{-4}$ to $1 \times 10^{-6}$ and unacceptable if the risks are surpassing $1 \times 10^{-4}$. A carcinogenic risk of $1 \times 10^{-4}$ poses health hazards; therefore, it is sufficiently large, poses health hazards, and need some sort of intervention and remediation [9].

$$
\mathrm{CR}=\mathrm{CDI} \times \mathrm{CSF}
$$

\section{Statistical analysis}

We used SPSS 17 (SPSS, Chicago, IL) and statistical software Excel 2007 (Microsoft Office) to calculate descriptive statistics. The bivariate analysis was performed to examine the significant variation of heavy metal in different groups.

\section{Results and discussion}

\section{Heavy metal distribution}

All information on the spatial variation of arsenic and toxic elements in drinking water from 35 stations are presented in Table 1. The average concentration of As and other heavy metals in drinking water were significantly different either at stations $(P<0.05, \mathrm{df}=25$, sig $<$ $0.001)$ or in sites $(P<0.05, \mathrm{df}=4, \mathrm{sig}=0.00)$. The high concentrations of $\mathrm{As}, \mathrm{Ni}, \mathrm{Hg}$, and $\mathrm{Pb}$ were measured in the west site (stations 23, 24, and 22) and north site (stations 4 and 6). The highest $\mathrm{Cr}$ concentration in water samples was measured in the center site (stations 32 and 34) and east site at the station 17. Studies elsewhere showed that several factors such as source water, pipeline corrosion, poor purification system, and water dynamics affect the concentration of heavy metals in pipeline drinking water $[34,35]$.

In this study, the water samples collected from the west part originated from groundwater and wells, and the high concentration of $\mathrm{As}, \mathrm{Ni}$, and $\mathrm{Pb}$ may be due to the concentration of natural metals in these sources. The geochemical studies conducted in the west of Mashhad proposed two different sources of heavy metals, which include the ophiolite rocks as the origin of $\mathrm{V}, \mathrm{Ni}$, $\mathrm{Pb}$, and $\mathrm{Fe}$ and acidic rocks as the origin of $\mathrm{Cd}, \mathrm{Cu}$, and As [36, 37]. Therefore, these heavy metals from ophiolite rocks and acidic rocks could be released into groundwater supplies and eventually contaminate these sources in the west region. Furthermore, it has been reported that heavy metals and As are the main pollutants of groundwater supplies in Mashhad [26, 29].

Likewise, the water samples collected from the center and eastern regions originated from Doosti dam water (at the border of Turkmenistan and Iran), and the high concentration of $\mathrm{Hg}$ and $\mathrm{Cr}$ might be related to the water quality of this dam. The recent studies showed that water in the Doosti dam is contaminated by $\mathrm{Cr}$ and $\mathrm{Hg}$ [37].

Peiravi et al. (2013) reported that the heavy metals are released into the Doosti dam through the industrial and agricultural processes in areas of land around Doosti dam. It was evidenced that the industrial and agricultural activities generate wastewaters, which are mostly discharged into this water supply. Industrial activities, especially plastic, chemical industries, and metal smelting, are major sources of heavy metals in water. These industries do not use advanced technologies for heavy metal removal, usually due to their limited economic capacities $[37,27]$. Furthermore, it was evidenced that pipeline transport in the center part of Mashhad was old [38]. This may affect the drinking water quality in this region. Therefore, suitable sanitation improvement programs should be used to protect the health of the residents in this area.

In an attempt at a rough comparison, heavy metal concentration was compared to other studies in Iran 
and other countries (Table 2). The average concentration of $\mathrm{As}, \mathrm{Pb}$, and $\mathrm{Hg}$ found in the drinking water from all sites were lower than that reported for drinking water from Ahvaz and Tehran [14, 16]. In terms of $\mathrm{Cr}$ and $\mathrm{Ni}$, there is still no report for drinking water in Tehran and Ahvaz as metropolitan cities in Iran $[14,16]$. The average of $\mathrm{Cr}$ content in drinking water in this study was lower in India [12], while its concentration was higher in Australia, China, Thailand, and Malaysia [1, 4, 10]. For $\mathrm{Pb}, \mathrm{Hg}$, and $\mathrm{Ni}$, the average content in drinking water was lower in Australia, China, Thailand, India, and Malaysia $[1,4,10]$. We found that the average concentration of As was lower than that reported values of drinking water from Australia, Thailand, India, and Malaysia. Likewise, the concentration of arsenic and heavy metals were compared with permissible levels set by the Iranian Ministry of Health, EPA, and WHO [2, 10]. Generally, the relative concentration of As and other heavy metals in this study were far below the permissible limits to assure safe consumption of drinking water (Table 2).

\section{Health risk assessment Average daily dose}

Exposure to arsenic and heavy metal contaminants through drinking water is a public health concern, and it is important that health risk assessments and impact on environmental health are investigated. Since no information is available regarding the non-carcinogenic effects through arsenic and heavy metals in drinking water of Mashhad, the average daily dose (ADD) of As and four toxic elements were measured through ingestion of drinking water and dermal absorption pathway (dishwashing, swimming, and bathing) (Table 3 and Table 4).

In this study, water ingestion accounted for the majority of $\mathrm{ADD}_{\text {total }}\left(\mathrm{ADD}_{\text {ingestion }}+\mathrm{ADD}_{\text {dermal }}\right.$ contact $)$ of $\mathrm{As}$ (2.13\%), $\mathrm{Hg}(0.17 \%), \mathrm{Pb}(6.38 \%), \mathrm{Cr}(63.89 \%)$, and $\mathrm{Ni}$ (20.80\%). The dermal pathway through water contributed a low portion $(6.77 \%)$ of $\mathrm{ADD}_{\text {total }}$ for $\mathrm{As}, \mathrm{Hg}, \mathrm{Pb}$, $\mathrm{Cr}$, and $\mathrm{Ni}$, which accounted for $0.25 \%, 0.83 \%, 2.91 \%$, and $2.76 \%$, respectively. The daily intakes of the $\mathrm{Cr}$ and $\mathrm{Ni}$ through drinking water ingestion played the most important contribution of $\mathrm{ADD}_{\text {total }}$ between both target groups. By contrast, the ADD values through the ingestion pathway were $\sim 3.2$ and 5.5 orders of magnitude higher than the ADD values through dermal absorption pathway (Fig. 2). Therefore, human exposure to arsenic and other toxic metals through water consumption is considered as the important pathways for heavy metal exposure. This result is in agreement with recent studies that reported the most important

Table 2 Arsenic and heavy metal concentrations $\left(\mu \mathrm{L} \mathrm{L}^{-1}\right)$ of drinking water samples collected in this study and comparison of elemental concentrations with other studies and water standard

\begin{tabular}{|c|c|c|c|c|c|}
\hline Heavy metals & As & $\mathrm{Hg}$ & $\mathrm{Pb}$ & $\mathrm{Cr}$ & $\mathrm{Ni}$ \\
\hline \multicolumn{6}{|l|}{ In this study $(n=140)$} \\
\hline North & $0.18 \pm 0.058$ & NA & $0.65 \pm 0.25$ & 4. $58 \pm 6.11$ & $1.49 \pm 0.88$ \\
\hline South & $0.17 \pm 0.042$ & NA & $0.65 \pm 0.99$ & $5.41 \pm 3.91$ & $0.77 \pm 0.46$ \\
\hline East & $0.17 \pm 0.060$ & NA & $0.52 \pm 0.12$ & $5.84 \pm 8.61$ & $0.83 \pm 0.67$ \\
\hline West & $0.23 \pm 0.08$ & $0.03 \pm 0.08$ & $0.67 \pm 0.32$ & $3.98 \pm 2.72$ & $3.59 \pm 4.31$ \\
\hline Center & $0.17 \pm 0.045$ & $0.04 \pm 0.02$ & $0.60 \pm 0.12$ & $4.91 \pm 6.33$ & $1.79 \pm 0.915$ \\
\hline \multicolumn{6}{|l|}{ Other cities } \\
\hline Ahvaz* [1] & $5.80 \pm 1.63$ & $2.8 \pm 0.3$ & $21.1 \pm 4.4$ & $5.3 \pm 3.6$ & - \\
\hline Tehran** [2] & $2.3 \pm 0.76$ & $0.52 \pm 0.03$ & $4.5 \pm 0.49$ & - & - \\
\hline \multicolumn{6}{|l|}{ Other countries } \\
\hline Australia [3] & $0.64 \pm 0.1$ & - & $5.21 \pm 1.43$ & $4.43 \pm 1.21$ & $7.93 \pm 2.4$ \\
\hline China [4] & - & $0.07 \pm 0.25$ & $5.06 \pm 1.73$ & $2.84 \pm 0.76$ & - \\
\hline Thailand $[5,6]$ & $1.06 \pm 1.74$ & $0.10 \pm 0.13$ & $16.7 \pm 18.5$ & $0.58 \pm 0.52$ & $6.13 \pm 4.38$ \\
\hline India [7] & $32 \pm 5.6$ & $0.76 \pm 0.32$ & $46.2 \pm 12.56$ & $28.3 \pm 4.9$ & $34.6 \pm 14.17$ \\
\hline Malaysia [8] & $2.51 \pm 0.65$ & $0.11 \pm 0.0 .6$ & $5.18 \pm 1.04$ & $2.19 \pm 0.93$ & $5.63 \pm 1.67$ \\
\hline \multicolumn{6}{|l|}{ Standards } \\
\hline WHO [9] & 10 & 6 & 10 & 50 & 70 \\
\hline EPA [6] & 10 & 2 & 15 & 100 & 20 \\
\hline Local standard in $\operatorname{Iran}^{\mathrm{a}}[10]$ & 10 & 6 & 10 & 50 & 70 \\
\hline
\end{tabular}

$N A$ lower then detection limit

*It is a city in the Southwest of Iran and the capital of Khuzestan province

**Capital of Iran

${ }^{\mathrm{a}}$ It was set by Iranian Ministry of Health 
Table 3 Descriptive statistics of estimated average daily dose (ADD) of heavy metals for adults and children through drinking water ingestion pathway

\begin{tabular}{|c|c|c|c|c|c|c|c|c|c|c|c|}
\hline \multirow{2}{*}{\multicolumn{2}{|c|}{ Sites/stations $(n=140)$}} & \multicolumn{10}{|c|}{ ADD of individuals heavy metals ( $\mu \mathrm{g} \mathrm{kg}^{-1}$ day $^{-1}$ ) } \\
\hline & & \multicolumn{2}{|c|}{ As } & \multicolumn{2}{|c|}{$\mathrm{Hg}$} & \multicolumn{2}{|l|}{$\mathrm{Pb}$} & \multicolumn{2}{|l|}{$\mathrm{Cr}$} & \multicolumn{2}{|l|}{$\mathrm{Ni}$} \\
\hline & & Adult & Child & Adult & Child & Adult & Child & Adult & Child & Adult & Child \\
\hline \multirow[t]{7}{*}{ North } & 1 & 0.005 & 0.017 & ND & ND & 0.030 & 0.093 & 0.015 & 0.047 & 0.044 & 0.137 \\
\hline & 2 & 0.005 & 0.016 & ND & ND & 0.015 & 0.047 & 0.020 & 0.064 & 0.032 & 0.101 \\
\hline & 3 & 0.004 & 0.014 & ND & ND & 0.025 & 0.079 & 0.035 & 0.109 & 0.114 & 0.360 \\
\hline & 4 & 0.010 & 0.030 & ND & ND & 0.038 & 0.120 & 0.215 & 0.678 & 0.044 & 0.138 \\
\hline & 5 & 0.005 & 0.017 & ND & ND & 0.017 & 0.055 & 0.097 & 0.307 & 0.056 & 0.175 \\
\hline & 6 & 0.009 & 0.028 & ND & ND & 0.025 & 0.079 & 0.130 & 0.411 & 0.067 & 0.212 \\
\hline & 7 & 0.007 & 0.023 & ND & ND & 0.013 & 0.041 & 0.631 & 1.988 & 0.016 & 0.051 \\
\hline \multirow[t]{7}{*}{ South } & 8 & 0.006 & 0.019 & ND & ND & 0.013 & 0.041 & 0.013 & 0.041 & 0.028 & 0.089 \\
\hline & 9 & 0.003 & 0.010 & ND & ND & 0.019 & 0.059 & 0.019 & 0.060 & 0.014 & 0.044 \\
\hline & 10 & 0.007 & 0.023 & ND & ND & 0.017 & 0.055 & 0.137 & 0.430 & 0.039 & 0.123 \\
\hline & 11 & 0.008 & 0.024 & ND & ND & 0.014 & 0.043 & 0.294 & 0.928 & 0.007 & 0.021 \\
\hline & 12 & 0.006 & 0.020 & ND & ND & 0.011 & 0.035 & 0.295 & 0.930 & 0.045 & 0.143 \\
\hline & 13 & 0.005 & 0.016 & ND & ND & 0.021 & 0.066 & 0.229 & 0.721 & 0.047 & 0.147 \\
\hline & 14 & 0.006 & 0.020 & ND & ND & 0.014 & 0.044 & 0.365 & 1.149 & 0.013 & 0.041 \\
\hline \multirow[t]{7}{*}{ East } & 15 & 0.004 & 0.011 & ND & ND & 0.012 & 0.037 & 0.024 & 0.077 & 0.010 & 0.032 \\
\hline & 16 & 0.007 & 0.021 & ND & ND & 0.018 & 0.058 & 0.399 & 1.257 & 0.008 & 0.026 \\
\hline & 17 & 0.004 & 0.014 & ND & ND & 0.013 & 0.042 & 0.830 & 2.616 & 0.061 & 0.193 \\
\hline & 18 & 0.010 & 0.032 & ND & ND & 0.022 & 0.070 & 0.017 & 0.053 & 0.065 & 0.204 \\
\hline & 19 & 0.008 & 0.024 & ND & ND & 0.018 & 0.056 & 0.020 & 0.064 & 0.013 & 0.039 \\
\hline & 20 & 0.005 & 0.017 & ND & ND & 0.020 & 0.063 & 0.021 & 0.066 & 0.021 & 0.065 \\
\hline & 21 & 0.006 & 0.018 & ND & ND & 0.027 & 0.084 & 0.149 & 0.468 & 0.031 & 0.097 \\
\hline \multirow[t]{7}{*}{ West } & 22 & 0.006 & 0.018 & 0.007 & 0.023 & 0.019 & 0.061 & 0.086 & 0.272 & 0.061 & 0.193 \\
\hline & 23 & 0.014 & 0.044 & ND & ND & 0.048 & 0.150 & 0.226 & 0.713 & 0.469 & 1.479 \\
\hline & 24 & 0.006 & 0.020 & ND & ND & 0.011 & 0.035 & 0.268 & 0.845 & 0.014 & 0.045 \\
\hline & 25 & 0.006 & 0.020 & ND & ND & 0.022 & 0.070 & 0.011 & 0.035 & 0.109 & 0.343 \\
\hline & 26 & 0.008 & 0.026 & ND & ND & 0.019 & 0.060 & 0.042 & 0.133 & 0.106 & 0.333 \\
\hline & 27 & 0.009 & 0.027 & ND & ND & 0.023 & 0.072 & 0.159 & 0.501 & 0.050 & 0.158 \\
\hline & 28 & 0.007 & 0.023 & ND & ND & 0.027 & 0.084 & 0.199 & 0.626 & 0.088 & 0.278 \\
\hline \multirow[t]{7}{*}{ Center } & 29 & 0.008 & 0.026 & ND & ND & 0.018 & 0.057 & 0.146 & 0.459 & 0.053 & 0.168 \\
\hline & 30 & 0.007 & 0.023 & ND & ND & 0.019 & 0.061 & 0.090 & 0.284 & 0.041 & 0.129 \\
\hline & 31 & 0.005 & 0.016 & ND & ND & 0.020 & 0.063 & 0.057 & 0.179 & 0.054 & 0.170 \\
\hline & 32 & 0.006 & 0.018 & 0.007 & 0.023 & 0.021 & 0.065 & 0.281 & 0.886 & 0.034 & 0.107 \\
\hline & 33 & 0.005 & 0.015 & ND & ND & 0.016 & 0.051 & 0.051 & 0.161 & 0.057 & 0.179 \\
\hline & 34 & 0.007 & 0.023 & 0.004 & 0.011 & 0.029 & 0.091 & 0.696 & 2.194 & 0.130 & 0.408 \\
\hline & 35 & 0.005 & 0.016 & ND & ND & 0.023 & 0.071 & 0.014 & 0.045 & 0.043 & 0.134 \\
\hline \multicolumn{2}{|l|}{ Mean } & 0.007 & 0.021 & 0.001 & 0.002 & 0.020 & 0.064 & 0.180 & 0.566 & 0.060 & 0.187 \\
\hline \multicolumn{2}{|c|}{ Standard deviation } & 0.002 & 0.006 & 0.002 & 0.005 & 0.007 & 0.023 & 0.199 & 0.628 & 0.077 & 0.242 \\
\hline
\end{tabular}

exposure pathway for heavy metals and arsenic in drinking water occurs through the ingestion route. Furthermore, the mean value of total ADD indicated that children were $\sim 3$ times more exposed to drinking water than adults (Fig. 2). This result was in accordance with several studies. They reported that the total heavy metal intake doses of children were significantly higher than adults. For instance, in 
Table 4 Descriptive statistics of estimated average daily dose (ADD) of heavy metals for adults and children through dermal intake of drinking water

\begin{tabular}{|c|c|c|c|c|c|c|c|c|c|c|c|}
\hline \multirow{2}{*}{\multicolumn{2}{|c|}{ Sites/stations $(n=140)$}} & \multicolumn{10}{|c|}{ ADD of individuals heavy metals $\left(\mu \mathrm{g} \mathrm{kg}^{-1}\right.$ day $\left.^{-1}\right)$} \\
\hline & & \multicolumn{2}{|c|}{ As } & \multicolumn{2}{|c|}{$\mathrm{Hg}$} & \multicolumn{2}{|l|}{$\mathrm{Pb}$} & \multicolumn{2}{|l|}{$\mathrm{Cr}$} & \multicolumn{2}{|l|}{$\mathrm{Ni}$} \\
\hline & & Adult & Child & Adult & Child & Adult & Child & Adult & Child & Adult & Child \\
\hline \multirow[t]{7}{*}{ North } & 1 & 0.001 & 0.005 & ND & ND & 0.006 & 0.029 & 0.003 & 0.015 & 0.009 & 0.043 \\
\hline & 2 & 0.001 & 0.005 & ND & ND & 0.003 & 0.015 & 0.004 & 0.020 & 0.006 & 0.032 \\
\hline & 3 & 0.001 & 0.004 & ND & ND & 0.005 & 0.025 & 0.007 & 0.034 & 0.023 & 0.112 \\
\hline & 4 & 0.002 & 0.009 & ND & ND & 0.008 & 0.037 & 0.043 & 0.211 & 0.009 & 0.043 \\
\hline & 5 & 0.001 & 0.005 & ND & ND & 0.003 & 0.017 & 0.019 & 0.095 & 0.011 & 0.054 \\
\hline & 6 & 0.002 & 0.009 & ND & ND & 0.005 & 0.025 & 0.026 & 0.128 & 0.013 & 0.066 \\
\hline & 7 & 0.001 & 0.007 & ND & ND & 0.003 & 0.013 & 0.126 & 0.618 & 0.003 & 0.016 \\
\hline \multirow[t]{7}{*}{ South } & 8 & 0.001 & 0.006 & ND & ND & 0.003 & 0.013 & 0.003 & 0.013 & 0.006 & 0.028 \\
\hline & 9 & 0.001 & 0.003 & ND & ND & 0.004 & 0.018 & 0.004 & 0.019 & 0.003 & 0.014 \\
\hline & 10 & 0.001 & 0.007 & ND & ND & 0.003 & 0.017 & 0.027 & 0.134 & 0.008 & 0.038 \\
\hline & 11 & 0.002 & 0.007 & ND & ND & 0.003 & 0.013 & 0.059 & 0.289 & 0.001 & 0.006 \\
\hline & 12 & 0.001 & 0.006 & ND & ND & 0.002 & 0.011 & 0.059 & 0.289 & 0.009 & 0.044 \\
\hline & 13 & 0.001 & 0.005 & ND & ND & 0.004 & 0.021 & 0.046 & 0.224 & 0.009 & 0.046 \\
\hline & 14 & 0.001 & 0.006 & ND & ND & 0.003 & 0.014 & 0.073 & 0.357 & 0.003 & 0.013 \\
\hline \multirow[t]{7}{*}{ East } & 15 & 0.001 & 0.004 & ND & ND & 0.002 & 0.012 & 0.005 & 0.024 & 0.002 & 0.010 \\
\hline & 16 & 0.001 & 0.007 & ND & ND & 0.004 & 0.018 & 0.080 & 0.391 & 0.002 & 0.008 \\
\hline & 17 & 0.001 & 0.004 & ND & ND & 0.003 & 0.013 & 0.166 & 0.814 & 0.012 & 0.060 \\
\hline & 18 & 0.002 & 0.010 & ND & ND & 0.004 & 0.022 & 0.003 & 0.016 & 0.013 & 0.064 \\
\hline & 19 & 0.002 & 0.007 & ND & ND & 0.004 & 0.017 & 0.004 & 0.020 & 0.002 & 0.012 \\
\hline & 20 & 0.001 & 0.005 & ND & ND & 0.004 & 0.020 & 0.004 & 0.021 & 0.004 & 0.020 \\
\hline & 21 & 0.001 & 0.006 & ND & ND & 0.005 & 0.026 & 0.030 & 0.146 & 0.006 & 0.030 \\
\hline \multirow[t]{7}{*}{ West } & 22 & 0.001 & 0.006 & 0.001 & 0.007 & 0.004 & 0.019 & 0.017 & 0.085 & 0.012 & 0.060 \\
\hline & 23 & 0.003 & 0.014 & ND & ND & 0.009 & 0.047 & 0.045 & 0.222 & 0.094 & 0.460 \\
\hline & 24 & 0.001 & 0.006 & ND & ND & 0.002 & 0.011 & 0.054 & 0.263 & 0.003 & 0.014 \\
\hline & 25 & 0.001 & 0.006 & ND & ND & 0.004 & 0.022 & 0.002 & 0.011 & 0.022 & 0.107 \\
\hline & 26 & 0.002 & 0.008 & ND & ND & 0.004 & 0.019 & 0.008 & 0.041 & 0.021 & 0.104 \\
\hline & 27 & 0.002 & 0.008 & ND & ND & 0.005 & 0.022 & 0.032 & 0.156 & 0.010 & 0.049 \\
\hline & 28 & 0.001 & 0.007 & ND & ND & 0.005 & 0.026 & 0.040 & 0.195 & 0.018 & 0.086 \\
\hline \multirow[t]{7}{*}{ Center } & 29 & 0.002 & 0.008 & ND & ND & 0.004 & 0.018 & 0.029 & 0.143 & 0.011 & 0.052 \\
\hline & 30 & 0.001 & 0.007 & ND & ND & 0.004 & 0.019 & 0.018 & 0.088 & 0.008 & 0.040 \\
\hline & 31 & 0.001 & 0.005 & ND & ND & 0.004 & 0.020 & 0.011 & 0.056 & 0.011 & 0.053 \\
\hline & 32 & 0.001 & 0.006 & 0.001 & 0.007 & 0.004 & 0.020 & 0.056 & 0.276 & 0.007 & 0.033 \\
\hline & 33 & 0.001 & 0.005 & ND & ND & 0.003 & 0.016 & 0.010 & 0.050 & 0.011 & 0.056 \\
\hline & 34 & 0.001 & 0.007 & 0.001 & 0.004 & 0.006 & 0.028 & 0.139 & 0.683 & 0.026 & 0.127 \\
\hline & 35 & 0.001 & 0.005 & ND & ND & 0.005 & 0.022 & 0.003 & 0.014 & 0.008 & 0.042 \\
\hline \multicolumn{2}{|l|}{ Mean } & 0.001 & 0.006 & 0.0009 & 0.001 & 0.004 & 0.020 & 0.036 & 0.176 & 0.012 & 0.058 \\
\hline \multicolumn{2}{|c|}{ Standard deviation } & 0.00021 & 0.002 & 0.00083 & 0.002 & 0.001 & 0.007 & 0.040 & 0.195 & 0.015 & 0.075 \\
\hline
\end{tabular}

Australia and Thailand, the average $\mathrm{ADD}_{\text {total }}$ values via the ingestion of drinking water in children populations were $\sim 1.7$ and 2.5 times higher than adults, respectively $[4,10]$.
Non-carcinogenic risk

A summary of HQ and HIs values for arsenic and four metals in drinking water through ingestion and dermal contacts with adults and children are presented in Fig. 3, Table 5, 

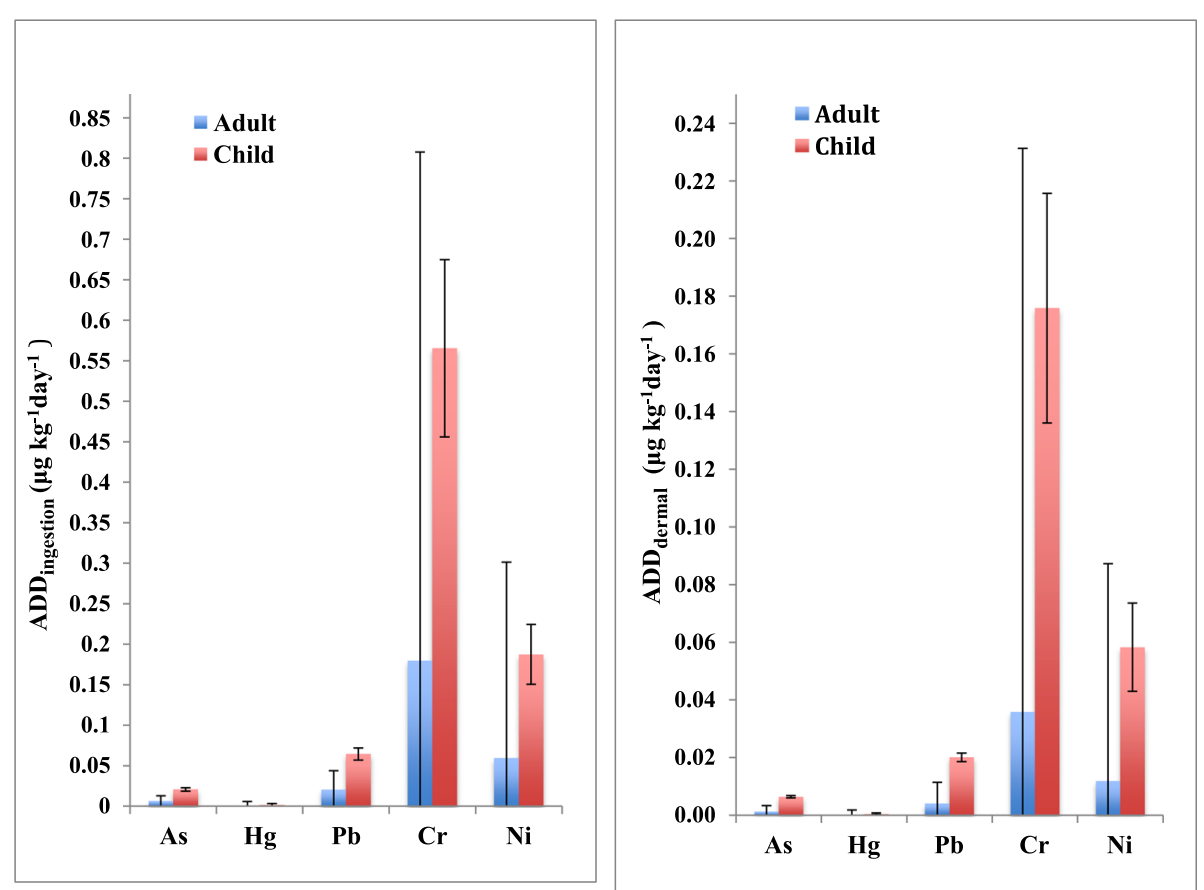

Fig. 2 Estimated average daily dose (ADD) for drinking water through ingestion and dermal contact by adult and children

and Table 6. As seen from the data, the $\mathrm{HQ}_{\text {ingestion }}$ and $\mathrm{HI}_{\mathrm{in}}$ gestion values through ingestion exposure did not exceed the threshold of HQ and HI for adults as well as children.

This suggested that the daily intake level of examined As and toxic metals were lower than the level of concern $(\mathrm{HQ}<1)$; therefore, the non-carcinogenic risk from heavy metals via ingestion of drinking water was in the safe range for children and adult population. Finding from our study is in agreement with results of other studies in Malaysia and Pakistan [2, 39].

In the case of the dermal pathway, the HQ and $\mathrm{HI}$ values never exceeded the level of concern for adult,

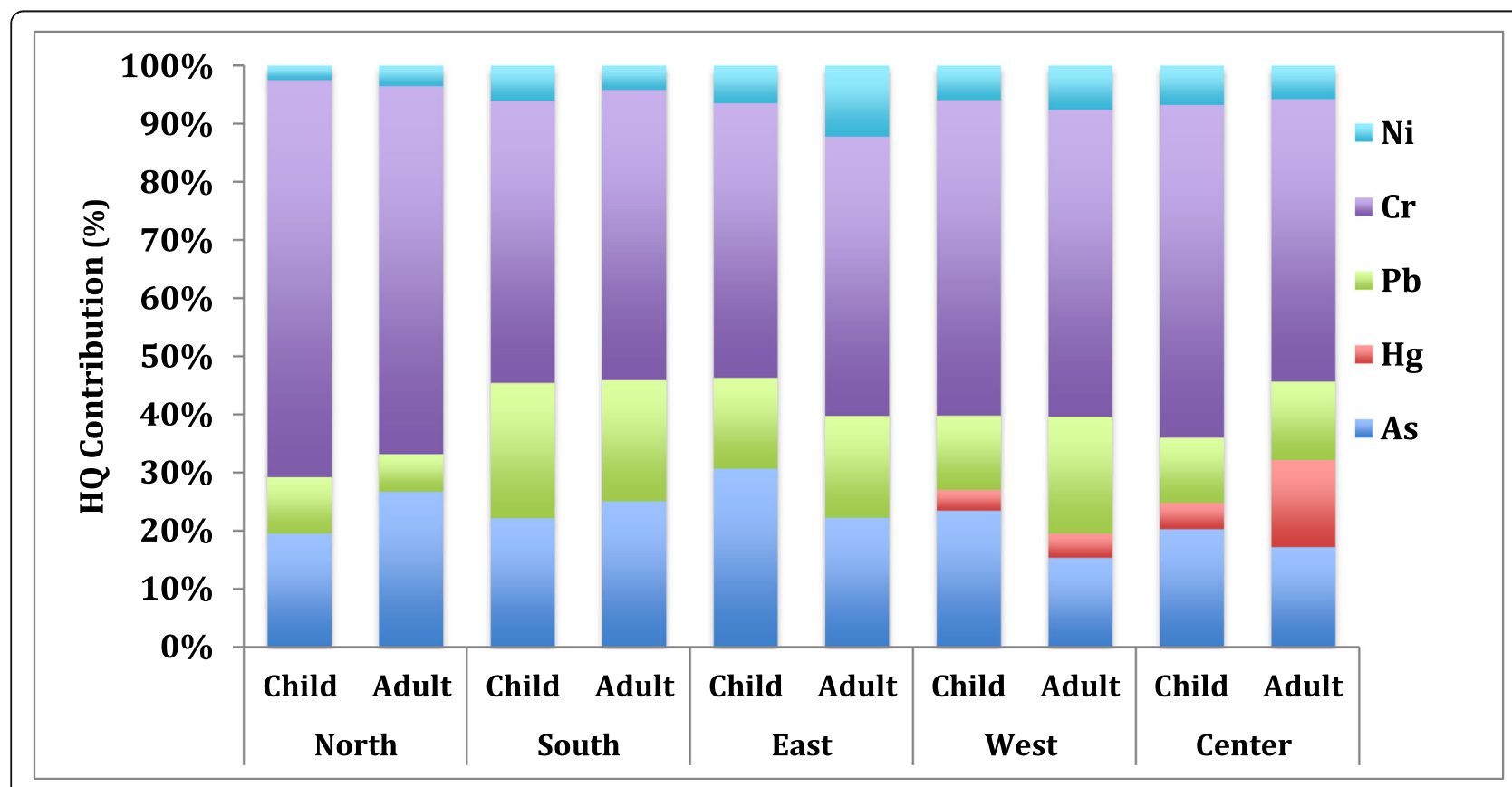

Fig. 3 Contribution of input variables on drinking water $\mathrm{HI}$ for two age groups 
Table 5 Target hazard quotient (THQ) and non-carcinogenic risk (HI) of heavy metals for adults and children through ingestion of drinking water

\begin{tabular}{|c|c|c|c|c|c|c|c|c|c|c|c|c|c|}
\hline \multirow{3}{*}{\multicolumn{2}{|c|}{ Sites/stations }} & \multicolumn{10}{|c|}{ THQ of individual heavy metals $(n=140)$} & \multirow{2}{*}{\multicolumn{2}{|c|}{$\frac{\sum \mathrm{THQ}}{\mathrm{HI}}$}} \\
\hline & & \multicolumn{2}{|c|}{ As } & \multicolumn{2}{|l|}{$\mathrm{Hg}$} & \multicolumn{2}{|l|}{$\mathrm{Pb}$} & \multicolumn{2}{|l|}{$\mathrm{Cr}$} & \multicolumn{2}{|l|}{$\mathrm{Ni}$} & & \\
\hline & & Adult & Child & Adult & Child & $\overline{\text { Adult }}$ & Child & Adult & Child & Adult & Child & Adult & Child \\
\hline \multirow[t]{7}{*}{ North } & 1 & 0.018 & 0.056 & 0.000 & 0.000 & 0.021 & 0.067 & 0.005 & 0.016 & 0.002 & 0.007 & 0.046 & 0.145 \\
\hline & 2 & 0.017 & 0.053 & 0.000 & 0.000 & 0.011 & 0.033 & 0.007 & 0.021 & 0.002 & 0.005 & 0.036 & 0.112 \\
\hline & 3 & 0.014 & 0.045 & 0.000 & 0.000 & 0.018 & 0.057 & 0.012 & 0.036 & 0.006 & 0.018 & 0.050 & 0.156 \\
\hline & 4 & 0.032 & 0.101 & 0.000 & 0.000 & 0.027 & 0.086 & 0.072 & 0.226 & 0.002 & 0.007 & 0.133 & 0.420 \\
\hline & 5 & 0.018 & 0.056 & 0.000 & 0.000 & 0.012 & 0.039 & 0.032 & 0.102 & 0.003 & 0.009 & 0.065 & 0.206 \\
\hline & 6 & 0.030 & 0.094 & 0.000 & 0.000 & 0.018 & 0.057 & 0.043 & 0.137 & 0.003 & 0.011 & 0.095 & 0.298 \\
\hline & 7 & 0.024 & 0.075 & 0.000 & 0.000 & 0.009 & 0.029 & 0.210 & 0.663 & 0.001 & 0.003 & 0.244 & 0.769 \\
\hline \multirow[t]{7}{*}{ South } & 8 & 0.020 & 0.064 & 0.000 & 0.000 & 0.009 & 0.029 & 0.004 & 0.014 & 0.001 & 0.004 & 0.035 & 0.111 \\
\hline & 9 & 0.011 & 0.034 & 0.000 & 0.000 & 0.013 & 0.042 & 0.006 & 0.020 & 0.001 & 0.002 & 0.031 & 0.098 \\
\hline & 10 & 0.024 & 0.075 & 0.000 & 0.000 & 0.012 & 0.039 & 0.046 & 0.143 & 0.002 & 0.006 & 0.084 & 0.264 \\
\hline & 11 & 0.025 & 0.079 & 0.000 & 0.000 & 0.010 & 0.031 & 0.098 & 0.309 & 0.000 & 0.001 & 0.133 & 0.420 \\
\hline & 12 & 0.021 & 0.068 & 0.000 & 0.000 & 0.008 & 0.025 & 0.098 & 0.310 & 0.002 & 0.007 & 0.130 & 0.409 \\
\hline & 13 & 0.017 & 0.053 & 0.000 & 0.000 & 0.015 & 0.047 & 0.076 & 0.240 & 0.002 & 0.007 & 0.110 & 0.348 \\
\hline & 14 & 0.021 & 0.068 & 0.000 & 0.000 & 0.010 & 0.032 & 0.122 & 0.383 & 0.001 & 0.002 & 0.154 & 0.484 \\
\hline \multirow[t]{7}{*}{ East } & 15 & 0.012 & 0.038 & 0.000 & 0.000 & 0.008 & 0.027 & 0.008 & 0.026 & 0.001 & 0.002 & 0.029 & 0.091 \\
\hline & 16 & 0.023 & 0.071 & 0.000 & 0.000 & 0.013 & 0.041 & 0.133 & 0.419 & 0.000 & 0.001 & 0.169 & 0.533 \\
\hline & 17 & 0.014 & 0.045 & 0.000 & 0.000 & 0.010 & 0.030 & 0.277 & 0.872 & 0.003 & 0.010 & 0.304 & 0.957 \\
\hline & 18 & 0.033 & 0.105 & 0.000 & 0.000 & 0.016 & 0.050 & 0.006 & 0.018 & 0.003 & 0.010 & 0.058 & 0.183 \\
\hline & 19 & 0.025 & 0.079 & 0.000 & 0.000 & 0.013 & 0.040 & 0.007 & 0.021 & 0.001 & 0.002 & 0.045 & 0.142 \\
\hline & 20 & 0.018 & 0.056 & 0.000 & 0.000 & 0.014 & 0.045 & 0.007 & 0.022 & 0.001 & 0.003 & 0.040 & 0.127 \\
\hline & 21 & 0.019 & 0.060 & 0.000 & 0.000 & 0.019 & 0.060 & 0.050 & 0.156 & 0.002 & 0.005 & 0.089 & 0.281 \\
\hline \multirow[t]{7}{*}{ West } & 22 & 0.019 & 0.060 & 0.024 & 0.075 & 0.014 & 0.043 & 0.029 & 0.091 & 0.003 & 0.010 & 0.088 & 0.279 \\
\hline & 23 & 0.046 & 0.146 & 0.000 & 0.000 & 0.034 & 0.107 & 0.075 & 0.238 & 0.023 & 0.074 & 0.179 & 0.565 \\
\hline & 24 & 0.021 & 0.068 & 0.000 & 0.000 & 0.008 & 0.025 & 0.089 & 0.282 & 0.001 & 0.002 & 0.119 & 0.376 \\
\hline & 25 & 0.021 & 0.068 & 0.000 & 0.000 & 0.016 & 0.050 & 0.004 & 0.012 & 0.005 & 0.017 & 0.047 & 0.147 \\
\hline & 26 & 0.027 & 0.086 & 0.000 & 0.000 & 0.014 & 0.043 & 0.014 & 0.044 & 0.005 & 0.017 & 0.060 & 0.190 \\
\hline & 27 & 0.029 & 0.090 & 0.000 & 0.000 & 0.016 & 0.051 & 0.053 & 0.167 & 0.003 & 0.008 & 0.100 & 0.316 \\
\hline & 28 & 0.024 & 0.075 & 0.000 & 0.000 & 0.019 & 0.060 & 0.066 & 0.209 & 0.004 & 0.014 & 0.113 & 0.357 \\
\hline \multirow[t]{7}{*}{ Center } & 29 & 0.027 & 0.086 & 0.000 & 0.000 & 0.013 & 0.041 & 0.049 & 0.153 & 0.003 & 0.008 & 0.091 & 0.288 \\
\hline & 30 & 0.024 & 0.075 & 0.000 & 0.000 & 0.014 & 0.043 & 0.030 & 0.095 & 0.002 & 0.006 & 0.070 & 0.220 \\
\hline & 31 & 0.017 & 0.053 & 0.000 & 0.000 & 0.014 & 0.045 & 0.019 & 0.060 & 0.003 & 0.009 & 0.053 & 0.166 \\
\hline & 32 & 0.019 & 0.060 & 0.024 & 0.075 & 0.015 & 0.046 & 0.094 & 0.295 & 0.002 & 0.005 & 0.153 & 0.482 \\
\hline & 33 & 0.015 & 0.049 & 0.000 & 0.000 & 0.011 & 0.036 & 0.017 & 0.054 & 0.003 & 0.009 & 0.047 & 0.148 \\
\hline & 34 & 0.024 & 0.075 & 0.012 & 0.038 & 0.021 & 0.065 & 0.232 & 0.731 & 0.006 & 0.020 & 0.295 & 0.929 \\
\hline & 35 & 0.017 & 0.053 & 0.000 & 0.000 & 0.016 & 0.051 & 0.005 & 0.015 & 0.002 & 0.007 & 0.040 & 0.125 \\
\hline \multicolumn{2}{|l|}{ Mean } & 0.022 & 0.069 & 0.002 & 0.005 & 0.015 & 0.046 & 0.060 & 0.189 & 0.003 & 0.009 & 0.101 & 0.318 \\
\hline \multicolumn{2}{|c|}{ Standard deviation } & 0.007 & 0.021 & 0.006 & 0.018 & 0.005 & 0.017 & 0.066 & 0.209 & 0.004 & 0.012 & 0.069 & 0.219 \\
\hline
\end{tabular}

while the HI for children was higher than the threshold of $\mathrm{HI}$ at stations $7,17,23$, and 34 .

This result showed that children suffered more adverse health risk through dermal contact with water due to their higher skin adherence compared to adults. As the result showed, the $\mathrm{HQ}_{\text {dermal contact }}$ of $\mathrm{Cr}$ determined for more than $63 \%$ of $\mathrm{HI}_{\text {dermal contact }}$ for children. This was consistent with the previous studies; they reported that dermal 
Table 6 Target hazard quotient (THQ) and non-carcinogenic risk (HI) of heavy metals for adults and children through dermal contact of drinking water

\begin{tabular}{|c|c|c|c|c|c|c|c|c|c|c|c|c|c|}
\hline \multirow{3}{*}{\multicolumn{2}{|c|}{ Sites/stations }} & \multicolumn{10}{|c|}{ THQ of individual heavy metals $(n=140)$} & \multirow{2}{*}{\multicolumn{2}{|c|}{$\frac{\sum \mathrm{THQ}}{\mathrm{HI}}$}} \\
\hline & & \multicolumn{2}{|l|}{ As } & \multicolumn{2}{|l|}{$\mathrm{Hg}$} & \multicolumn{2}{|l|}{$\mathrm{Pb}$} & \multicolumn{2}{|l|}{$\mathrm{Cr}$} & \multicolumn{2}{|l|}{$\mathrm{Ni}$} & & \\
\hline & & Adult & Child & Adult & Child & Adult & Child & Adult & Child & Adult & Child & Adult & Child \\
\hline \multirow[t]{7}{*}{ North } & 1 & 0.004 & 0.019 & 0.000 & 0.000 & 0.011 & 0.055 & 0.004 & 0.194 & 0.011 & 0.053 & 0.030 & 0.321 \\
\hline & 2 & 0.004 & 0.018 & 0.000 & 0.000 & 0.006 & 0.028 & 0.005 & 0.026 & 0.008 & 0.039 & 0.023 & 0.111 \\
\hline & 3 & 0.003 & 0.015 & 0.000 & 0.000 & 0.010 & 0.047 & 0.009 & 0.045 & 0.029 & 0.140 & 0.050 & 0.247 \\
\hline & 4 & 0.007 & 0.034 & 0.000 & 0.000 & 0.014 & 0.071 & 0.057 & 0.281 & 0.011 & 0.054 & 0.090 & 0.440 \\
\hline & 5 & 0.004 & 0.019 & 0.000 & 0.000 & 0.007 & 0.032 & 0.026 & 0.127 & 0.014 & 0.068 & 0.050 & 0.246 \\
\hline & 6 & 0.006 & 0.031 & 0.000 & 0.000 & 0.010 & 0.047 & 0.035 & 0.170 & 0.017 & 0.082 & 0.067 & 0.331 \\
\hline & 7 & 0.005 & 0.025 & 0.000 & 0.000 & 0.005 & 0.024 & 0.168 & 0.825 & 0.004 & 0.020 & 0.182 & 0.894 \\
\hline \multirow[t]{7}{*}{ South } & 8 & 0.004 & 0.021 & 0.000 & 0.000 & 0.005 & 0.024 & 0.003 & 0.017 & 0.007 & 0.035 & 0.020 & 0.097 \\
\hline & 9 & 0.002 & 0.011 & 0.000 & 0.000 & 0.007 & 0.035 & 0.005 & 0.025 & 0.004 & 0.017 & 0.018 & 0.088 \\
\hline & 10 & 0.005 & 0.025 & 0.000 & 0.000 & 0.007 & 0.032 & 0.036 & 0.179 & 0.010 & 0.048 & 0.058 & 0.284 \\
\hline & 11 & 0.005 & 0.026 & 0.000 & 0.000 & 0.005 & 0.026 & 0.078 & 0.385 & 0.002 & 0.008 & 0.091 & 0.445 \\
\hline & 12 & 0.005 & 0.023 & 0.000 & 0.000 & 0.004 & 0.021 & 0.079 & 0.386 & 0.011 & 0.056 & 0.099 & 0.484 \\
\hline & 13 & 0.004 & 0.018 & 0.000 & 0.000 & 0.008 & 0.039 & 0.061 & 0.299 & 0.012 & 0.057 & 0.084 & 0.413 \\
\hline & 14 & 0.005 & 0.023 & 0.000 & 0.000 & 0.005 & 0.026 & 0.097 & 0.476 & 0.003 & 0.016 & 0.110 & 0.541 \\
\hline \multirow[t]{7}{*}{ East } & 15 & 0.003 & 0.013 & 0.000 & 0.000 & 0.004 & 0.022 & 0.006 & 0.032 & 0.002 & 0.012 & 0.016 & 0.078 \\
\hline & 16 & 0.005 & 0.024 & 0.000 & 0.000 & 0.007 & 0.034 & 0.106 & 0.521 & 0.002 & 0.010 & 0.120 & 0.589 \\
\hline & 17 & 0.003 & 0.015 & 0.000 & 0.000 & 0.005 & 0.025 & 0.221 & 1.085 & 0.015 & 0.075 & 0.244 & 1.200 \\
\hline & 18 & 0.007 & 0.035 & 0.000 & 0.000 & 0.008 & 0.042 & 0.004 & 0.022 & 0.016 & 0.079 & 0.036 & 0.178 \\
\hline & 19 & 0.005 & 0.026 & 0.000 & 0.000 & 0.007 & 0.033 & 0.005 & 0.026 & 0.003 & 0.015 & 0.021 & 0.101 \\
\hline & 20 & 0.004 & 0.019 & 0.000 & 0.000 & 0.008 & 0.037 & 0.006 & 0.028 & 0.005 & 0.025 & 0.022 & 0.109 \\
\hline & 21 & 0.004 & 0.020 & 0.000 & 0.000 & 0.010 & 0.050 & 0.040 & 0.194 & 0.008 & 0.038 & 0.061 & 0.302 \\
\hline \multirow[t]{7}{*}{ West } & 22 & 0.004 & 0.020 & 0.005 & 0.023 & 0.007 & 0.036 & 0.023 & 0.113 & 0.015 & 0.075 & 0.054 & 0.267 \\
\hline & 23 & 0.010 & 0.049 & 0.000 & 0.000 & 0.018 & 0.089 & 0.060 & 0.296 & 0.117 & 0.575 & 0.205 & 1.008 \\
\hline & 24 & 0.005 & 0.023 & 0.000 & 0.000 & 0.004 & 0.021 & 0.071 & 0.350 & 0.004 & 0.018 & 0.084 & 0.411 \\
\hline & 25 & 0.005 & 0.023 & 0.000 & 0.000 & 0.008 & 0.042 & 0.003 & 0.015 & 0.027 & 0.133 & 0.043 & 0.212 \\
\hline & 26 & 0.006 & 0.029 & 0.000 & 0.000 & 0.007 & 0.035 & 0.011 & 0.055 & 0.026 & 0.130 & 0.051 & 0.249 \\
\hline & 27 & 0.006 & 0.030 & 0.000 & 0.000 & 0.009 & 0.043 & 0.042 & 0.208 & 0.013 & 0.061 & 0.070 & 0.342 \\
\hline & 28 & 0.005 & 0.025 & 0.000 & 0.000 & 0.010 & 0.050 & 0.053 & 0.259 & 0.022 & 0.108 & 0.090 & 0.442 \\
\hline \multirow[t]{7}{*}{ Center } & 29 & 0.006 & 0.029 & 0.000 & 0.000 & 0.007 & 0.034 & 0.039 & 0.190 & 0.013 & 0.065 & 0.065 & 0.318 \\
\hline & 30 & 0.005 & 0.025 & 0.000 & 0.000 & 0.007 & 0.036 & 0.024 & 0.118 & 0.010 & 0.050 & 0.047 & 0.229 \\
\hline & 31 & 0.004 & 0.018 & 0.000 & 0.000 & 0.008 & 0.037 & 0.015 & 0.074 & 0.013 & 0.066 & 0.040 & 0.195 \\
\hline & 32 & 0.004 & 0.020 & 0.005 & 0.023 & 0.008 & 0.038 & 0.075 & 0.368 & 0.008 & 0.042 & 0.100 & 0.491 \\
\hline & 33 & 0.003 & 0.016 & 0.000 & 0.000 & 0.006 & 0.030 & 0.014 & 0.067 & 0.014 & 0.070 & 0.037 & 0.183 \\
\hline & 34 & 0.005 & 0.025 & 0.002 & 0.012 & 0.011 & 0.054 & 0.185 & 0.910 & 0.032 & 0.159 & 0.236 & 1.159 \\
\hline & 35 & 0.004 & 0.018 & 0.000 & 0.000 & 0.009 & 0.042 & 0.004 & 0.019 & 0.011 & 0.052 & 0.027 & 0.131 \\
\hline \multicolumn{2}{|l|}{ Mean } & 0.005 & 0.023 & 0.000 & 0.002 & 0.008 & 0.038 & 0.048 & 0.240 & 0.015 & 0.073 & 0.075 & 0.375 \\
\hline \multicolumn{2}{|c|}{ Standard deviation } & 0.001 & 0.007 & 0.001 & 0.006 & 0.003 & 0.014 & 0.053 & 0.258 & 0.019 & 0.094 & 0.059 & 0.285 \\
\hline
\end{tabular}

contact with $\mathrm{Cr}$ contributed to higher non-carcinogenic risk compared to other exposure routes $[17,40]$.

Furthermore, $\mathrm{Cr}$ showed the highest average contribution of $\mathrm{HI}_{\text {total elements }}$ (55 to $71.2 \%$ ) for adult and child population (Fig. 3). It seems $\mathrm{Cr}$ could be the most hazardous element in the case of non-carcinogen risk. Notably, the $\mathrm{Cr}^{6+}$ is much more toxic than $\mathrm{Cr}^{3+}$ and other metals that were used to assess human exposure 
Table 7 Descriptive statistics of total carcinogenic risk (carcinogenic risk through ingestion and dermal combined) for children and adults

\begin{tabular}{|c|c|c|c|c|c|c|c|c|c|}
\hline \multicolumn{2}{|c|}{ Sites/stations $(n=140)$} & \multicolumn{8}{|c|}{ Carcinogenic risk (CR) } \\
\hline & & \multicolumn{2}{|l|}{ As } & \multicolumn{2}{|l|}{$\mathrm{Pb}$} & \multicolumn{2}{|l|}{$\mathrm{Cr}$} & \multicolumn{2}{|l|}{ Total CR } \\
\hline & & Adult & Child & Adult & Child & Adult & Child & Adult & Child \\
\hline \multirow[t]{7}{*}{ North } & 1 & $7.98 \mathrm{E}-06$ & $1.71 \mathrm{E}-05$ & $2.5 \mathrm{E}-05$ & $4.03 \mathrm{E}-05$ & $3.81 E-06$ & $6.63 \mathrm{E}-06$ & $3.77 E-05$ & $6.41 \mathrm{E}-05$ \\
\hline & 2 & 7.44E-06 & $1.60 \mathrm{E}-05$ & $1.2 \mathrm{E}-05$ & $2.29 \mathrm{E}-05$ & $5.18 \mathrm{E}-06$ & $9.02 \mathrm{E}-06$ & $2.56 \mathrm{E}-05$ & 4.79E-05 \\
\hline & 3 & $6.38 \mathrm{E}-06$ & 1.37E-05 & $2.2 \mathrm{E}-05$ & 3.39E-05 & $8.90 \mathrm{E}-06$ & $1.55 E-05$ & $3.73 \mathrm{E}-05$ & $6.31 E-05$ \\
\hline & 4 & $1.44 \mathrm{E}-05$ & $3.09 \mathrm{E}-05$ & $3.3 \mathrm{E}-05$ & $5.50 \mathrm{E}-05$ & $5.53 \mathrm{E}-05$ & $9.63 \mathrm{E}-05$ & $1.03 \mathrm{E}-04$ & $1.82 \mathrm{E}-04$ \\
\hline & 5 & 7.98E-06 & $1.71 \mathrm{E}-05$ & $1.5 \mathrm{E}-05$ & $2.62 \mathrm{E}-05$ & $2.50 \mathrm{E}-05$ & $4.35 E-05$ & $4.81 \mathrm{E}-05$ & $8.68 \mathrm{E}-05$ \\
\hline & 6 & $1.33 \mathrm{E}-05$ & $2.46 \mathrm{E}-05$ & $2.2 \mathrm{E}-05$ & $3.04 \mathrm{E}-05$ & $3.35 \mathrm{E}-05$ & $5.03 E-05$ & $6.88 \mathrm{E}-05$ & $1.26 \mathrm{E}-04$ \\
\hline & 7 & $1.06 \mathrm{E}-05$ & $2.29 E-05$ & $1.1 \mathrm{E}-05$ & $2.34 \mathrm{E}-05$ & $1.62 \mathrm{E}-04$ & $2.82 \mathrm{E}-04$ & 1.84E-04 & $3.28 \mathrm{E}-04$ \\
\hline \multirow[t]{7}{*}{ South } & 8 & $9.04 \mathrm{E}-06$ & $1.94 \mathrm{E}-05$ & $1.1 \mathrm{E}-05$ & $2.19 \mathrm{E}-05$ & 3.30E-06 & $5.75 E-06$ & $2.36 \mathrm{E}-05$ & 4.71E-05 \\
\hline & 9 & $4.79 \mathrm{E}-06$ & $1.03 \mathrm{E}-05$ & $1.6 \mathrm{E}-05$ & $2.53 \mathrm{E}-05$ & 4.91E-06 & $8.54 \mathrm{E}-06$ & $2.61 \mathrm{E}-05$ & 4.41E-05 \\
\hline & 10 & $1.06 \mathrm{E}-05$ & $2.29 \mathrm{E}-05$ & $1.5 \mathrm{E}-05$ & $2.03 \mathrm{E}-05$ & $3.51 \mathrm{E}-05$ & $5.11 \mathrm{E}-05$ & $6.09 E-05$ & $1.12 \mathrm{E}-04$ \\
\hline & 11 & $1.12 \mathrm{E}-05$ & $2.40 \mathrm{E}-05$ & $1.2 \mathrm{E}-05$ & 2.46E-05 & 7.57E-05 & $1.32 \mathrm{E}-04$ & $9.88 \mathrm{E}-05$ & $1.80 \mathrm{E}-04$ \\
\hline & 12 & $9.57 \mathrm{E}-06$ & $2.06 \mathrm{E}-05$ & $9.6 \mathrm{E}-06$ & 2.03E-05 & $7.58 \mathrm{E}-05$ & $1.32 \mathrm{E}-04$ & $9.51 E-05$ & $1.73 E-04$ \\
\hline & 13 & 7.44E-06 & 1.60E-05 & $1.8 \mathrm{E}-05$ & 3.01E-05 & $5.88 \mathrm{E}-05$ & $1.02 \mathrm{E}-04$ & 8.47E-05 & $1.48 \mathrm{E}-04$ \\
\hline & 14 & 9.57E-06 & $2.06 \mathrm{E}-05$ & $1.2 \mathrm{E}-05$ & 2.37E-05 & 9.37E-05 & $1.63 \mathrm{E}-04$ & 1.16E-04 & 2.07E-04 \\
\hline \multirow[t]{7}{*}{ East } & 15 & $5.32 \mathrm{E}-06$ & $1.14 \mathrm{E}-05$ & 1.0E-05 & $1.77 \mathrm{E}-05$ & $6.24 \mathrm{E}-06$ & $1.09 E-05$ & $2.18 \mathrm{E}-05$ & 4.00E-05 \\
\hline & 16 & $1.01 \mathrm{E}-05$ & 2.17E-05 & 1.6E-05 & $2.91 \mathrm{E}-05$ & $1.02 \mathrm{E}-04$ & $1.78 \mathrm{E}-04$ & $1.29 \mathrm{E}-04$ & $2.29 \mathrm{E}-04$ \\
\hline & 17 & $6.38 \mathrm{E}-06$ & 1.37E-05 & 1.1E-05 & $2.04 \mathrm{E}-05$ & $2.13 \mathrm{E}-04$ & $3.71 E-04$ & $2.31 \mathrm{E}-04$ & 4.05E-04 \\
\hline & 18 & 1.49E-05 & $3.20 \mathrm{E}-05$ & 1.9E-05 & 3.74E-05 & 4.31E-06 & 7.50E-06 & 3.87E-05 & $7.69 E-05$ \\
\hline & 19 & $1.12 \mathrm{E}-05$ & $2.40 \mathrm{E}-05$ & $1.5 E-05$ & $2.91 \mathrm{E}-05$ & $5.18 \mathrm{E}-06$ & $9.02 \mathrm{E}-06$ & $3.18 \mathrm{E}-05$ & $6.21 \mathrm{E}-05$ \\
\hline & 20 & $7.98 \mathrm{E}-06$ & $1.71 \mathrm{E}-05$ & 1.7E-05 & $2.93 \mathrm{E}-05$ & $5.41 \mathrm{E}-06$ & $9.42 \mathrm{E}-06$ & $3.08 \mathrm{E}-05$ & $5.58 \mathrm{E}-05$ \\
\hline & 21 & $8.51 \mathrm{E}-06$ & $1.43 \mathrm{E}-05$ & $2.3 \mathrm{E}-05$ & $3.75 \mathrm{E}-05$ & $3.52 \mathrm{E}-05$ & $5.24 \mathrm{E}-05$ & $7.01 E-05$ & $1.22 \mathrm{E}-04$ \\
\hline \multirow[t]{7}{*}{ West } & 22 & $8.51 \mathrm{E}-06$ & $1.83 \mathrm{E}-05$ & 1.6E-05 & $2.89 \mathrm{E}-05$ & $2.22 \mathrm{E}-05$ & $3.86 \mathrm{E}-05$ & $4.75 E-05$ & $8.57 \mathrm{E}-05$ \\
\hline & 23 & 2.07E-05 & 4.46E-05 & 4.1E-05 & 7.09E-05 & $5.82 \mathrm{E}-05$ & $1.01 E-04$ & $1.20 E-04$ & $2.17 \mathrm{E}-04$ \\
\hline & 24 & 9.57E-06 & 2.06E-05 & $9.6 \mathrm{E}-06$ & $2.03 \mathrm{E}-05$ & $6.89 \mathrm{E}-05$ & $5.20 E-05$ & 8.81E-05 & $1.61 \mathrm{E}-04$ \\
\hline & 25 & 9.57E-06 & 2.06E-05 & $1.9 \mathrm{E}-05$ & $3.32 \mathrm{E}-05$ & $2.89 \mathrm{E}-06$ & $5.03 \mathrm{E}-06$ & 3.19E-05 & $5.88 \mathrm{E}-05$ \\
\hline & 26 & $1.22 \mathrm{E}-05$ & $2.63 \mathrm{E}-05$ & $1.6 \mathrm{E}-05$ & $3.14 \mathrm{E}-05$ & 1.09E-05 & $1.89 E-05$ & 3.96E-05 & $7.66 \mathrm{E}-05$ \\
\hline & 27 & $1.28 \mathrm{E}-05$ & $2.74 \mathrm{E}-05$ & 2.0E-05 & 3.63E-05 & 4.09E-05 & $5.11 \mathrm{E}-05$ & 7.36E-05 & 1.35E-04 \\
\hline & 28 & $1.06 \mathrm{E}-05$ & $2.29 E-05$ & $2.3 E-05$ & $3.89 \mathrm{E}-05$ & $5.10 \mathrm{E}-05$ & $6.88 \mathrm{E}-05$ & $8.49 E-05$ & $1.51 \mathrm{E}-04$ \\
\hline \multirow[t]{7}{*}{ Center } & 29 & $1.22 \mathrm{E}-05$ & $2.63 \mathrm{E}-05$ & $1.5 \mathrm{E}-05$ & $3.04 \mathrm{E}-05$ & $3.74 \mathrm{E}-05$ & $6.51 E-05$ & $6.54 \mathrm{E}-05$ & $1.22 \mathrm{E}-04$ \\
\hline & 30 & 1.06E-05 & $2.29 \mathrm{E}-05$ & $1.6 \mathrm{E}-05$ & $3.05 \mathrm{E}-05$ & 2.32E-05 & 4.03E-05 & $5.06 \mathrm{E}-05$ & 9.37E-05 \\
\hline & 31 & 7.44E-06 & $1.60 \mathrm{E}-05$ & 1.7E-05 & $2.88 \mathrm{E}-05$ & $1.46 \mathrm{E}-05$ & $2.54 \mathrm{E}-05$ & $3.95 E-05$ & $7.02 \mathrm{E}-05$ \\
\hline & 32 & $8.51 \mathrm{E}-06$ & $1.83 \mathrm{E}-05$ & 1.7E-05 & $3.03 \mathrm{E}-05$ & $7.23 \mathrm{E}-05$ & $1.26 \mathrm{E}-04$ & $9.87 E-05$ & $1.74 \mathrm{E}-04$ \\
\hline & 33 & $6.91 \mathrm{E}-06$ & $1.49 \mathrm{E}-05$ & $1.4 \mathrm{E}-05$ & $2.39 \mathrm{E}-05$ & $1.32 \mathrm{E}-05$ & $2.29 E-05$ & $3.41 \mathrm{E}-05$ & $6.17 \mathrm{E}-05$ \\
\hline & 34 & $1.06 \mathrm{E}-05$ & $2.29 \mathrm{E}-05$ & $2.5 \mathrm{E}-05$ & 4.16E-05 & $1.79 E-04$ & $3.11 E-04$ & $2.15 E-04$ & $3.76 \mathrm{E}-04$ \\
\hline & 35 & 7.44E-06 & $1.60 \mathrm{E}-05$ & $1.9 \mathrm{E}-05$ & $3.19 \mathrm{E}-05$ & 3.67E-06 & $6.39 \mathrm{E}-06$ & $3.09 E-05$ & $5.43 \mathrm{E}-05$ \\
\hline \multicolumn{2}{|l|}{ Mean } & $9.78 \mathrm{E}-06$ & $2.10 \mathrm{E}-05$ & 1.7E-05 & $3.12 \mathrm{E}-05$ & 4.61E-05 & $8.03 E-05$ & $7.38 \mathrm{E}-05$ & $1.33 \mathrm{E}-04$ \\
\hline \multicolumn{2}{|c|}{ Standard deviation } & 3.07E-06 & $6.61 \mathrm{E}-06$ & $6.5 \mathrm{E}-06$ & $1.03 \mathrm{E}-05$ & $5.20 \mathrm{E}-05$ & $9.05 E-05$ & $5.25 \mathrm{E}-05$ & $9.20 \mathrm{E}-05$ \\
\hline
\end{tabular}

in this study. However, $\mathrm{Cr}^{6+}$ is decreased into $\mathrm{Cr}^{3+}$ in the human body; thus, there might be an overestimation in determining health risk $[17,41]$. It should be noted that the $\mathrm{HI}_{\text {total }}$ elements $\left(\mathrm{HQ}_{\text {ingestion }}+\mathrm{HQ}_{\text {dermal }}\right.$ contact $)$ values for children were higher than that of an adult, suggesting that children were more susceptible to noncarcinogenic risk from the heavy metals. This result is in agreement with the results reported in Australia [10] 
and the Hong Kong Environmental Protection Department [1].

\section{Carcinogenic risk}

The cancer risk was determined based on the intake level of inorganic $\mathrm{As}, \mathrm{Pb}$ and $\mathrm{Cr}$, which may increase carcinogenic effects depending on the exposure dose $[33,42]$. Briefly, based on dermal exposure, the chance of developing $\mathrm{CR}_{\text {dermal contact }}$ for all elements ranged from $9.62 \times 10^{-7}$ to $8.72 \times 10^{-5}$, and its average values for children and adults were $3.4 \times 10^{-5}$ and $6.42 \times 10^{-6}$, respectively. Thus, the $\mathrm{CR}_{\text {dermal contact }}$ values were below the safety level $\left(1 \times 10^{-4}\right)$ recommended by the US EPA, suggesting carcinogenic risk can be acceptable for both adult and children in Mashhad through dermal contact (Additional file 1: Table S2).

Considering ingestion exposure pathways, estimated $\mathrm{CR}_{\text {ingestion }}$ for all elements was in the range of $1.65 \times$ $10^{-6}$ to $8.05 \times 10^{-5}$ for adults and in $5.07 \times 10^{-6}$ to $2.84 \times$ $10^{-4}$ for children (Additional file 1: Table S2). The average values of $\mathrm{CR}_{\text {ingestion }}$ for adults and children were $4.38 \times 10^{-5}$ and $1.27 \times 10^{-4}$, respectively. This suggested that the probability of carcinogenic risk for children via the consumption of drinking water collected from
Mashhad was 1.27 in 10000, while for adult was 4.38 in 100,000 , indicating the potential $\mathrm{CR}_{\text {ingestion }}$ for the children population from lifetime exposure to the carcinogenic elements ( $\mathrm{As}, \mathrm{Pb}$, and $\mathrm{Cr}$ ) via ingestion of drinking water in Mashhad, Iran. The study also found that $\mathrm{Cr}$ had the highest average contribution of TCR (63.2\%) compared to other carcinogenic elements such as $\mathrm{Pb}$ (24.0\%) and As (15.7\%) (Table 7). It seems that $\mathrm{Cr}$ could be the most hazardous element in the case of carcinogen risk.

Based on the total $\mathrm{CR}\left(\mathrm{TCR}=\mathrm{CR}_{\text {dermal contact }}+\mathrm{CR}_{\text {inges- }}\right.$ tion) values, the chance of developing $\mathrm{CR}$ ranged from $2.36 \times 10^{-5}$ to $3.76 \times 10^{-4}$, and its average values for children and adults were $1.33 \times 10^{-4}$ and $7.38 \times 10^{-5}$, respectively (Table 7 and Fig. 4). This result confirmed a potential cancer risk for the children as a highly exposed population to the carcinogenic elements via ingestion and dermal routes, particularly at stations $4,7,14,16$, $17,23,32$, and 34. However, a potential TCR was borderline $\left(1 \times 10^{-4}\right.$ to $\left.1 \times 10^{-6}\right)$ for the adult population. Therefore, the consumption of drinking water in this area could be large enough to warrant action under Superfund guidelines and may pose detrimental health hazards to the exposed population $[1,9,10]$. With

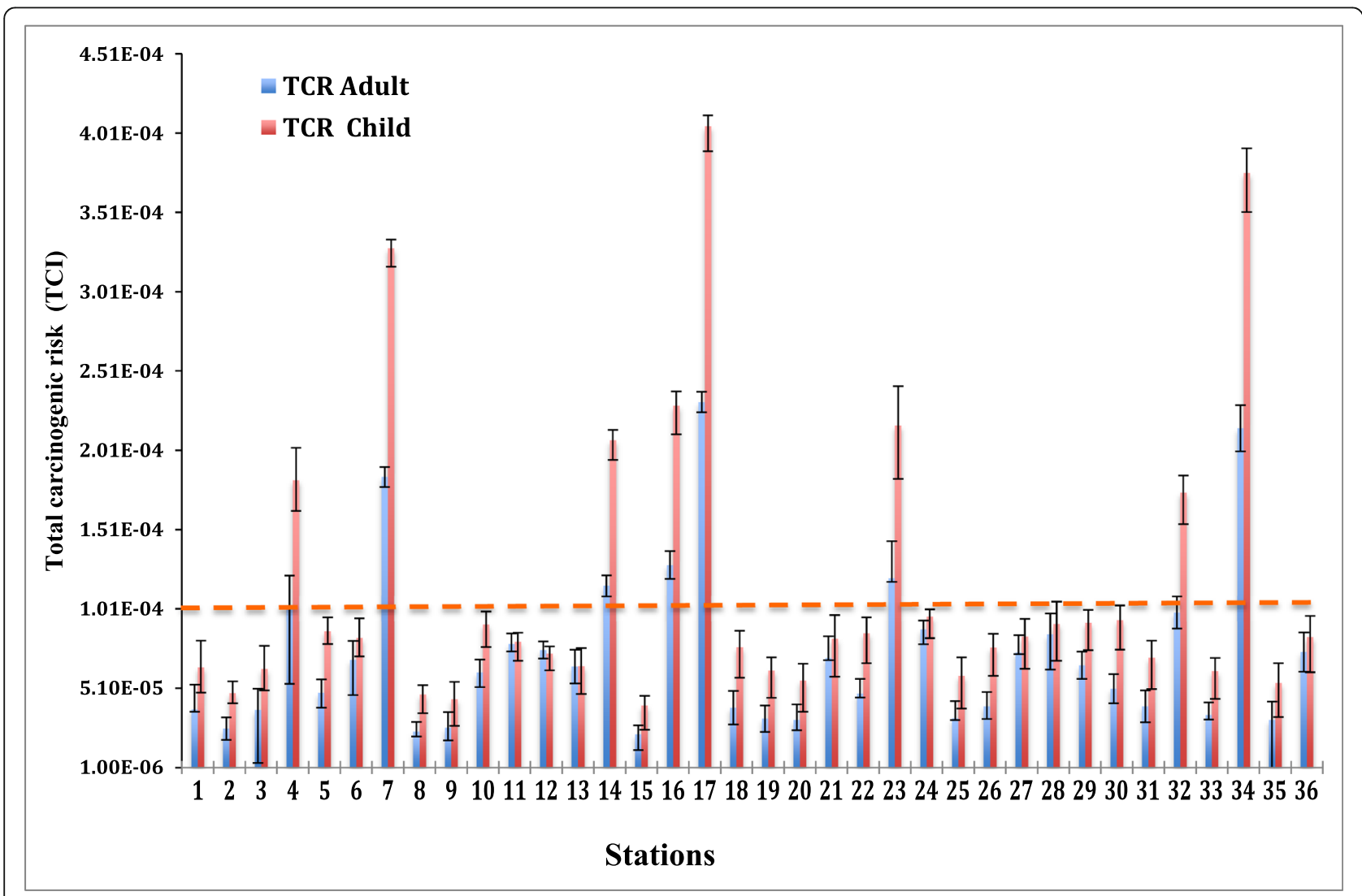

Fig. 4 Estimated total carcinogenic risk (total) for drinking water through ingestion and dermal contact by adult and children 
regard to the different pathways, the contribution of dermal exposure was lower than (40.2\% for adult and 32.4\% for children) digestion exposure to the TCR, which is in consistence with more recent studies $[1,10]$.

It is noteworthy to indicate that the estimated TCR was higher for children compared to adults, suggesting that children were more susceptible to CR from the As and heavy metals. According to the recent World Health Organization (WHO) report, children are a vulnerable population to health risks because they drink more water, consume more food, and breathe more air in proportion to their weight. Children's immune, digestive, reproductive, and nervous systems are still growing. At the early part of development, exposure to toxic elements causes irreversible damage [43]. According to the finding, all stations require some intervention, remediation, and control measures to decrease the level of carcinogenic heavy metals. It is suggested that appropriate purification improvement programs should be implemented to protect the health of the residents in this metropolitan city, especially from stations $4,7,14$, $16,17,23,32$, and 34 .

\section{Uncertainty of risk}

In this work, there is the possibility of uncertainties that may not be taken into account and could consider as a limitation for the validity of the risk estimation. For instance, (i) body weights and daily intake of drinking water were not estimated for the people who live in Mashhad, (ii) most of the probability variables applied for estimation were derived from the US EPA guideline which may not apply to this population, (iii) CSF of As and $\mathrm{Pb}$ was only used to assess $\mathrm{CR}$ because there is no real CSF value available for other toxic metals, (iv) CSF was considered as a constant for all individuals, but in reality, CSF can change between individuals, and (v) the health risk was only assessed using the heavy metal toxicity, but the fact is that drinking water also contains other chemicals from possible exposure. Thus, the level of risk from drinking water in Mashhad may be higher than that estimated values in this work.

\section{Conclusion}

In this study, the health risk assessment of heavy metals was evaluated based on daily intake and exposure through dermal absorption and ingestion of drinking water of the two selected populations of adults and children. Likewise, we focused on two populations for health risks assessment, including adult and children (as a sensitive population). Drinking water ingestion was the main metal exposure routes for Mashhad residents, followed by dermal contact pathway. For both target groups, the daily heavy metal intakes via water consumption were at least four to ten times higher than those via dermal contact. For dermal exposure, the non-carcinogenic and carcinogenic risk level for arsenic and heavy metals never exceeded the US EPA risk management criterion, suggesting there is no health risk threat from heavy metals for adults and children. However, risk evaluation showed that for children at stations $7,17,23$, 3and 4, there is non-carcinogenic risk via dermal contact. Risk evaluation indicated that the carcinogenic risk from the consumption of drinking water based on ingestion exposure was borderline or higher than the safety level of US EPA risk; therefore, residents in this study area might suffer more health risk and serious attention must be given in this area. The exposure assessments exhibited children might suffer more carcinogenic and non-carcinogen risk via ingestion and dermal contact routes, and residents in Mashhad was more exposed to Cr. Likewise, the uncertainty of risk explained major variables for the probabilistic health risk determination; therefore, health risk via consumption of drinking water could be higher than that estimated values. More efforts are needed to reduce the heavy metal level in drinking water in Mashhad, such as appropriate purification system and the control of the heavy metal discharge. Furthermore, proper use of wastewater treatment plants must be implemented to protect the local population and reduce human health risks.

\section{Additional file}

Additional file 1: Table S1. ICP-MS operating measurement. Table S2. Descriptive statistics of total carcinogenic risk (carcinogenic risk through ingestion and dermal combined) for children and adult. (DOCX $28 \mathrm{~kb}$ )

\section{Abbreviations \\ ADD: Average daily dose; AT: Averaging time; BW: Body weight; \\ CF: Conversion factor; EC: Electrical conductivity; ED: Exposure duration; EF: Exposure frequency; HHRA: Human health risk assessment; HI: Hazard index; HQ: Hazard quotients; IARC: Agency for Research on Cancer; IR: Ingestion rate; LOD: Limit of detection; RFD: Reference dose; SA: Skin surface; TCR: Total carcinogenic risk; THQ: Target hazard quotient; US EPA: United States Environmental Protection Agency; WHO: World Health Organization}

\section{Acknowledgements}

The authors would like to thank the vice president of research at the Mashhad University of Medical Sciences, the chiefs of the health centers affiliated with the university, and the esteemed patients. We would also like to extend our appreciation to all participants and data collectors.

\section{Authors' contributions}

BZGO involved in the writing up of the research proposal, performed the sampling and laboratory analysis, presented the results, and is the corresponding author. HA initiated the research concept, interpreted the results, and finalized the manuscript document. SBTS presented the results and discussions, interpreted the results, and wrote up of the draft manuscript. MT and HSH performed the laboratory analysis and analyzed the data. MF analyzed the data and was involved in the manuscript reviewing. All authors read and approved the final manuscript. 


\section{Availability of data and materials}

The datasets generated and analyzed during this study are included in the main document of this manuscript.

\section{Ethics approval and consent to participate}

We obtained ethical clearance from the Mashhad University of Medical Science.

\section{Consent for publication}

Not applicable

\section{Competing interests}

The authors declare that they have no competing interests.

\section{Author details}

${ }^{1}$ Department of Environmental Health Engineering, Faculty of Health, Mashhad University of Medical Science, Mashhad, Iran. ${ }^{2}$ Department of Health Education and Health Promotion, Faculty of Health, Mashhad University of Medical Sciences, Mashhad, Iran. ${ }^{3}$ Students Research Committee, Mashhad University of Medical Sciences, Mashhad, Iran. ${ }^{4}$ Social Determinants of Health Research Center, Mashhad University of Medical Sciences, Mashhad, Iran. ${ }^{5}$ Chemistry Department, Islamic Azad University of Mashhad, Mashhad, Iran. 'Statistics Department, Khorasan Razavi Regional Water Authority, Mashhad, Iran. ${ }^{7}$ Khorasan Razavi Regional Water Authority, Mashhad, Iran

\section{Received: 27 February 2019 Accepted: 27 August 2019}

\section{Published online: 14 September 2019}

\section{References}

1. Rajeshkumar $\mathrm{S}$, et al. Studies on seasonal pollution of heavy metals in water, sediment, fish and oyster from the Meiliang Bay of Taihu Lake in China. Chemosphere. 2018;191:626-38.

2. Ahmad N, Jaafar MS, Alsaffar MS. Study of radon concentration and toxic elements in drinking and irrigated water and its implications in Sungai Petani, Kedah, Malaysia. Journal of Radiation Research and Applied Sciences. 2015;8(3):294-9.

3. Sany SBT, et al. Integrated ecological risk assessment of dioxin compounds. Environmental Science and Pollution Research. 2015;22(15):11193-208.

4. Wongsasuluk $P$, et al. Heavy metal contamination and human health risk assessment in drinking water from shallow groundwater wells in an agricultural area in Ubon Ratchathani province, Thailand. Environmental geochemistry and health. 2014:36(1):169-82.

5. Hashemi $M$, et al. Health risk assessment for human exposure to trace metals and arsenic via consumption of hen egg collected from largest poultry industry in Iran. Biological Trace Element Research. 2018;6:1-9.

6. World Health, O., Guidelines for drinking-water quality. 2011. Available on http://apps.who.int/iris/bitstream/10665/44584/1/9789241548151_eng. pdf, 2015

7. WHO, Progress on sanitation and drinking-water: Fast facts. 2013: World Health Organization, Download the full 2013 report at http://www.wssinfo. org and http://www.who.int/water_sanitation_health/en/index.html.

8. Geremew A, et al. Appropriate household water treatment methods in Ethiopia: household use and associated factors based on 2005, 2011 and 2016 EDHS data. Environmental health and preventive medicine. 2018;23(1):46

9. EPA. Edition of the Drinking Water Standards and Health Advisories. 2012: EPA 822-S-12-001. Washington, DC: Office of Water U.S. Environmental Protection Agency; 2012

10. Saha $\mathrm{N}$, et al. Industrial metal pollution in water and probabilistic assessment of human health risk. Journal of environmental management. 2017; 185:70-8

11. Chowdhury $\mathrm{S}$, et al. Heavy metals in drinking water: occurrences, implications, and future needs in developing countries. Science of the total Environment. 2016:569:476-88.

12. Bajwa BS, et al. Uranium and other heavy toxic elements distribution in the drinking water samples of SW-Punjab, India. Journal of Radiation Research and Applied Sciences. 2017;10(1):13-9.

13. Edition F. Guidelines for drinking-water quality. WHO chronicle. 2011 38(4):104-8
14. Hadiani MR, et al. Trace elements and heavy metals in mineral and bottled drinking waters on the Iranian market. Food Additives \& Contaminants: Part B. 2015;8(1):18-24.

15. Mosaferi $\mathrm{M}$, et al. Prevalence of skin lesions and exposure to arsenic in drinking water in Iran. Science of the total environment. 2008;390(1):69-76.

16. Savari J, et al. Heavy metals leakage and corrosion potential in Ahvaz drinking water distribution network. Water Wastewater J. 2008;18(64):16-24.

17. Li Y, et al. Concentrations and health risk assessment of metal (loid) s in indoor dust from two typical cities of China. Environmental Science and Pollution Research. 2016;23(9):9082-92.

18. Wang $D$, et al. Total arsenic and speciation analysis of saliva and urine samples from individuals living in a chronic arsenicosis area in China. Environmental health and preventive medicine. 2017:22(1):45.

19. USEPA. Dermal Exposure Assessment: A Summary of EPA Approaches; 2007 p. 20460.

20. Sany SBT, et al. Ecological quality assessment based on macrobenthic assemblages indices along West Port, Malaysia coast. Environmental earth sciences. 2015;74(2):1331-41.

21. Mazloomy Mahmoodabad SS, et al. The effect of social class on the amount of salt intake in patients with hypertension. Blood pressure. 2016;25(6):360-3.

22. USEPA. Risk Assessment Guidance for Superfund Volume I: Human Health Evaluation Manual (Part E, Supplemental Guidance for Dermal Risk Assessment). Washington, DC, USA: EPA/540/R/99/005. OSWER 9285. 7-02EP PB99-963312; 2004

23. Dawoud EA, Purucker S. Quantitative uncertainty analysis of superfund residential risk pathway models for soil and groundwater: White Paper. Lockheed Martin Energy Systems, Inc., US Department of Energy; 1996. p. 6.

24. Siuki HA, et al. Health education intervention on HIV/AIDS prevention behaviors among health volunteers in healthcare centers: an applying the theory of planned behavior. Journal of Social Service Research. 2018:2:1-7.

25. Mousavi SR, et al. Concentrations of mercury, lead, chromium, cadmium, arsenic and aluminum in irrigation water wells and wastewaters used for agriculture in Mashhad, northeastern Iran. Int J Occup Environ Med (The IJOEM). 2013:4(2 April):200-80-6.

26. Alidadi $\mathrm{H}$, et al. Survey of heavy metals concentration in Mashhad drinking water in 2011. Razi Journal of Medical Sciences. 2014;20(116):27-34

27. Khashei-Siuki A, Sarbazi M. Evaluation of ANFIS, ANN, and geostatistical models to spatial distribution of groundwater quality (case study: Mashhad plain in Iran). Arabian Journal of Geosciences. 2015;8(2):903-12.

28. rahim Rahnama M, Homaeefar A, Piruz T. Evaluating of Mashhad urban development plans from compact city viewpoint. American Journal of Engineering Research. 2013;02(09):208-213.

29. Shad R, Khorrami M, Ghaemi M. Developing an Iranian green building assessment tool using decision making methods and geographical information system: case study in Mashhad city. Renewable and Sustainable Energy Reviews. 2017;67:324-40.

30. Federation WE. American Public Health, Standard methods for the examination of water and wastewater. Washington, DC: American Public Health Association (APHA): 2005.

31. AQUASTAT, AQUASTAT, 2008. Country Fact Sheet: Iran. FAO's global information system on water and agriculture. Available at http://www.fao. org/nr/water/aquastat/countries_regions/irn/index.stm. 2008.

32. USEPA, Region 9, Regional screening levels tables. http://www.epa.gov/ region9/superfund/prg/index.html. 2010.

33. EPA, U., Integrated Risk Information Sys- tem. https://www.epa.gov/iris/ (accessed 14.10.16). 2016, U.S. Environmental Protection Agency: Washington

34. Aligol $\mathrm{M}$, et al. Physical activity and associated factors among women in a suburban area: findings of a community-based study in Iran. Journal of Fundamental and Applied Sciences. 2017;9(1S):1313-26.

35. Rojas C, Romero A, Cruzans G. Examining drinking water supplies in western Paraguay. Environmental Earth Sciences. 2017;76(16):1-6.

36. Karimi A, et al. Impacts of geology and land use on magnetic susceptibility and selected heavy metals in surface soils of Mashhad plain, northeastern Iran. Journal of Applied Geophysics. 2017;138:127-34.

37. Zhiltsov SS, et al. Water resources in central Asia: international context. Springer; 2012;3(11)

38. Peiravi $R$, et al. Heavy metals concentrations in Mashhad drinking water network. Zahedan Journal of Research in Medical Sciences. 2013:15(9):74-6.

39. Muhammad S, Shah MT, Khan S. Health risk assessment of heavy metals and their source apportionment in drinking water of Kohistan region, northern Pakistan. Microchemical Journal. 2011;98(2):334-43. 
40. Wang R, et al. Concentrations and exposure evaluation of metals in diverse food items from Chengdu, China. Archives of environmental contamination and toxicology. 2018;74(1):131-9.

41. Cuong AM, et al. Melanin-embedded materials effectively remove hexavalent chromium (Cr VI) from aqueous solution. Environmental health and preventive medicine. 2018;23(1):9.

42. Garg VK, et al. Heavy metals bioconcentration from soil to vegetables and assessment of health risk caused by their ingestion. Biological trace element research. 2014;157(3):256-65.

43. Peek $L$, et al. Children and disasters, in Handbook of disaster research: Springer; 2018. vol. 8. p. 243-62.

\section{Publisher's Note}

Springer Nature remains neutral with regard to jurisdictional claims in published maps and institutional affiliations.

Ready to submit your research? Choose BMC and benefit from:

- fast, convenient online submission

- thorough peer review by experienced researchers in your field

- rapid publication on acceptance

- support for research data, including large and complex data types

- gold Open Access which fosters wider collaboration and increased citations

- maximum visibility for your research: over $100 \mathrm{M}$ website views per year

At BMC, research is always in progress.

Learn more biomedcentral.com/submissions 